\title{
DIALOGISMO \\ DAS “VOZES” E \\ HETEROGENEIDADE \\ CONSTITUTIVA DO SENTIDO. \\ O "LITERÁRIO”: \\ SEMELHANÇAS E \\ DIFERENÇAS DE ACENTUAÇÃO \\ EM VOLOCHINOV, BAKHTIN E VIGOTSKI
}

Frédéric François*

Université Paris Descartes

Traduzido por Dóris de Arruda C. da Cunha**

\section{ADVERTÊNCIA}

Este texto não pretende apresentar um "pensamento original". Também não é um trabalho erudito sobre os autores em questão. Retomo aqui um curso destinado a alguns professores sobre o que pode ser a especificidade da recepção do objeto "literatura" - e do discurso que se pode fazer sobre ela - em um diálogo muito rápido com esses três autores. Mas, nessa versão, suprimimos as considerações propriamente pedagógicas para manter apenas algumas considerações certamente instáveis sobre a leitura literária.

\footnotetext{
1 N.T. : Tradução do artigo Dialogisme des "voix" et hétérogénéité constitutive du "sens". Le "savoir", le "quotidien" et le "littéraire", communauté et différences d'accentuation chez Volochinov, Bakhtine et Vygotzki. Une contribution indirecte à la pédagogie du "texte littéraire", publicado numa versão mais condensada em Investigações - Linguística e Teoria Literária, Recife, v. 19, n. 2, 2006, p. 79-141. Agradecemos a Frédéric François, que nos enviou uma versão mais longa para esta tradução com uma mudança no título e autorizou a publicação na revista Fórum Linguístico; a Fabiele Stockmans De Nardi, que cedeu os direitos de tradução e publicação do artigo, e a Heber de Oliveira Costa e Silva pela leitura cuidadosa do texto.

O original em francês pode ser acessado em: <http://www.repositorios.ufpe.br/revistas/index.php/INV/article/view/1441>.
}

* Professor honorário em Linguística na Université Paris Descartes, França

** Universidade Federal de Pernambuco/Universidade Católica de Pernambuco/CNPq. E-mail: dorisarrudacunha@gmail.com. 
Uma primeira dificuldade: estudar as relações entre o pensamento de Vigotski e o de Bakhtin é uma tentativa fadada ao fracasso, dado o volume de obras e a variedade de movimentos do pensamento de cada autor, movimentos que não têm nada de unívocos. Especialmente porque Vigotski produziu muito em uma vida relativamente breve (1896-1934), e Bakhtin também escreveu bastante, mas numa vida longa (1895-1975), deixando muitos textos inéditos. Daí a impossibilidade para mim (para nós) de recuperar o movimento global do seu pensamento.

Acrescentam-se a isso dificuldades mais específicas. Dentre elas, o duplo problema ligado ao estado parcial das traduções e a minha ignorância das línguas, especialmente do russo, bem como as especificidades do que significa "pensar em uma língua".

Vale acrescentar que agora me parece necessário distinguir completamente a contribuição dos dois livros de Volochinov, que constituem um pensamento diferente daquele de Bakhtin, em razão, entre outras, da releitura de textos de Gardin dedicados a essa questão ${ }^{2}$ e da leitura do artigo de Charles Bazerman (2004): Intertextualities: Voloshinov, Bakhtin, Literary Theory, and Literacy Studies. Qualquer que tenha sido a história real de suas relações em uma "escola de Bakhtin”, os textos de um e de outro contêm, ao mesmo tempo, fortes convergências e diferenças consideráveis de acentuação. Por outro lado, também, vou tentar esclarecer as semelhanças e as diferenças entre Bakhtin e Vigotski, sem me preocupar com eventuais influências que explicariam essas relações.

Outra causa de insuficiência dessas reflexões é a dificuldade de se reconstruir o quadro intelectual desses pensamentos. Colocar os autores em seu tempo é um trabalho de historiador que não estou certo de poder fazer bem. Por exemplo, a linguística de Marr é, suponho, pouco conhecida pela maioria de nós. Há uma obra de Patrick Sériot - Um paradigma perdido: a linguística marrista - e posso apenas indicar algumas direções que ele aponta. Ademais, não sou formado para o trabalho de historiador das ideias nem é possível seguir a regra de objetividade mínima, que consiste em não dissimular nada nem modificar conscientemente. Mas, é claro, tanto a exaustividade quanto encontrar a "verdadeira perspectiva" em que tudo isso se organizaria é outra questão. Posso apenas constatar que Volochinov cita Marr frequentemente, nunca de forma crítica, e também que as obras fazem sentido para além de suas "condições de produção", sentido que está em constante transformação. Além disso, não há algo unívoco que pudesse ser considerado o quadro, a perspectiva "da" modernidade e menos ainda a vitória final "da" verdade. Exceto o fato de não estarmos, por exemplo, na perspectiva "marxista revolucionária" ou projetando o futuro sobre o passado, "pré-stalinista", tal como era em 1920, com a efervescência de ideias correspondentes. Também não estamos confrontados aos mesmos "outros", "idealistas", "formalistas", "marristas" ou "pavlovianos". Pode-se ainda acrescentar, para caracterizar nossa época, a multiplicação de conhecimentos, por exemplo, em neurologia, com grande número de publicações e a intensidade de circulação desses conhecimentos, mas também uma imagem do futuro no mínimo conturbada. No entanto, não há nenhuma ligação automática entre uma época e um campo de pensamento. Nem Vigotski, nem Bakhtin, nem Volochinov são apenas "homens de seu tempo". Quanto a nós, obviamente, não podemos dizer muito sobre a nossa conexão com o nosso tempo, exceto que não podemos dar conta do conjunto de elementos que organiza nossa recepção. Por isso, não vou tentar tratar das relações de Volochinov e Vigotski com Freud.

\section{ALGUMAS ORIENTAÇÕES BÁSICAS}

Gostaria de explicitar, em primeiro lugar, algumas orientações para ilustrar as limitações da abordagem aqui apresentada, apoiandome em dois autores próximos, mas “externos”.

a) Para começar, o texto de Gardin O dizer difícil e o dever dizer, que sintetiza, para mim, a questão do "exterior à linguagem”, como o que não é apenas o contexto em que as palavras adquirem sentido, mas sobretudo o que resiste ao discurso. Essa reflexão me parece necessária para falar concretamente da linguagem e, mais especificamente, dos "gêneros de linguagem" efetivos, e não da "língua". O artigo de Gardin apenas levanta a questão, abrindo três perspectivas:

${ }^{2}$ Bernard (2005).

François | Trad. Cunha | Dialogismo das "vozes" e heterogeneidadeconstitutiva do sentido. o "literário" 
- o que pode explicar a dificuldade de elaborar um dizer? A lista é heterogênea, é o preço a pagar: "um branco", a sensação de que falta a palavra;

- as censuras, os tabus, os "enunciados sacralizados" e as "morais linguageiras", a subestimação linguística e a não legitimação do falante; o excesso de pressões; o conflito dos interpretantes; os conflitos decorrentes do quadro da comunicação.

Por outro lado, coloca-se a questão do que nos leva a "dizer apesar de tudo". Gardin se baseia na situação do discurso sindical contra o discurso patronal. Mas cada um de nós, suponho, tem seus exemplos de tais conflitos.

Essa dificuldade de dizer, pode se traduzir, finalmente, por incompletude, balbucio, mudança de semiótica (falamos com o corpo), "desespero", retorno à linguagem estereotipada, retomada paródica do discurso do outro, pressão na língua, fazendo-a dizer para além da norma.

Gardin conclui lembrando aquilo que marca o sucesso de uma tentativa de superar esse difícil de dizer no discurso dos outros, eventualmente o uso bem-sucedido de fórmulas, transformando a invenção em lugar-comum...

Como sabemos, Politzer procurava opor uma psicologia concreta à psicologia das faculdades. Parece-me que há uma relação entre a sua tentativa, a de Gardin e o que estamos tentando propor sob a égide protetora desses nomes. Trata-se do que poderia ser uma descrição (relativamente) "concreta” dos movimentos dos discursos (é a isso que nos limitaremos aqui), dos signos, ou mesmo dos modos de ser dos humanos, em oposição aos conhecimentos que buscam tratar apenas do genérico das leis, das estruturas, das instâncias ou das funções psíquicas. Em primeiro lugar, não é só por prudência que colocamos entre parênteses “relativamente”. $\mathrm{O}$ que acontece na vida dos homens está sujeito a constantes mudanças e pode, por outro lado, ser sempre recolocado pelos próprios participantes ou terceiros espectadores ${ }^{3}$ em um número indefinido de perspectivas. Apreender "completamente" o sentido concreto de um ato é ainda mais absurdo do que tentar descrever completamente os movimentos das folhas de uma árvore agitada pelo vento. Podemos apenas nos questionar os modos de contextualizar o que estamos estudando, para antecipar o que será dito a partir de Bakhtin, tentar esclarecer primeiro não a língua dos textos, mas os gêneros de discurso, ou melhor, as variações perpétuas do modo de ação dos discursos sobre os destinatários. O que supõe também esclarecer o pano de fundo ${ }^{4}$ não dito, pressuposto ou aberto pela recepção do texto. Existem aí dois tipos de resistência ao dizer: a do objeto de que se fala que o discurso nunca torna completamente transparente. E também a do efeito do discurso sobre o receptor, efeito que resiste mais ou menos a um processo de elaboração do discurso $^{5}$ adequada. E poderíamos acrescentar aqui as dificuldades específicas de se abordar textos oriundos de uma cultura distante, cujos panos de fundo nos escapam, tanto quanto as especificidades bizarras da linguagem silenciosa que fala continuamente em nós. Mas, para nos limitarmos a nossa relação com os autores não muito distantes, podemos começar nos questionando sobre nossa maneira de recebê-los, sobre os diferentes modos de compreendê-los, fora do mito de uma "paráfrase perfeitamente transparente". Por exemplo, questionaremos o modo de compreensão "estranha" que vem do fato de um texto nos fascinar justamente porque estamos distantes, não teríamos sido capazes de produzi-lo, não sabemos contextualizá-lo, em suma, não temos certeza de compreendê-lo. A diversidade das condições da compreensão é provavelmente ainda maior do que a de se tomar a palavra. Ela faz, de todo modo, duvidar da falsa evidência de uma relação simples entre nós, as palavras e as coisas. Ademais, uma vez que é isso que constitui o horizonte deste ensaio, é difícil dar uma imagem concreta do que pode ser ajudar os "outros", supostamente menos "competentes" e, em todo caso, diferentes uns dos outros, a se tornarem melhores leitores, capazes de variação em seus modos de apreensão dos textos e em sua compreensão do não dito através dos textos, sempre com os riscos de não dizer nada que já não tenha sido dito ou pensado.

\footnotetext{
${ }^{3}$ N.T.: O terceiro é usado pelo autor no sentido bakhtiniano.

${ }^{4}$ N.T.: Noção usada por Frédéric François (2009) aqui para se referir aos implícitos, ao conjunto de elementos da situação extraverbal, da "cena” na qual os discursos se constituem; ele usa também para se referir a background, conjunto de competências e experiências.

${ }^{5}$ N.T.: O autor utiliza mise en mots, que significa literalmente "colocação em palavras". Optamos por processo de elaboração do discurso porque, para o autor, a mise en mots é uma noção que poderia implicar que se trata de um conteúdo já completamente organizado que é em seguida "colocado em palavras". No entanto, o processo de elaboração do discurso, segundo François, modifica a experiência de "colocar em palavras".
} 
b) Isso nos leva a um segundo ponto, talvez ainda mais geral, que seria a impossibilidade de separar "sentido" e "força". Eu não gostaria de correr o risco de começar com uma "boa definição" de "sentido" e "força". Justamente porque essas palavras, como todas as "grandes palavras", não são designadoras de conceitos unívocos, mas lugares de conflito e de reacentuações. Seja como for, tendemos a considerar em primeiro lugar o "sentido" em termos de explicação possível: “o que isso quer dizer?", e não em termos de "como isso age em você?" Mas ao mesmo tempo, muitas vezes temos menos a fazer com o nonsense como indecifrável do que com o conjunto do que não tem força para nós, não nos diz respeito, nos é indiferente ou fora do âmbito de nossas preocupações. O que ilustra, pelo menos negativamente, a articulação do discurso com uma certa "força", mesmo que o sentido permaneça opaco. Podemos distinguir aqui a questão da "força" em si (ou para outros), a do modo como sentimos essa força e a da "representação" abstrata que nós damos dela, por exemplo, quando falamos de "afetos".

Poderíamos propor principalmente que considerar a linguagem em termos de diálogo, e não de enunciados "por si mesmos", leva à impossibilidade de separar o que são os signos como força e como capacidade de representação. O dizer do outro vai primeiramente me colocar em movimento, me entusiasmar, me indignar, me questionar. Ou, pelo contrário, eu tomo isso como a mesma ladainha, com a possibilidade também de uma ação progressiva em mim, sem que eu perceba no momento. Assim como a capacidade que temos de falar para nós mesmosé acompanhada, pelo menos às vezes, de preocupação referente a “de onde me vem isso?”. Da mesma forma, agem em nós, sem que saibamos bem como, a culpa, a vergonha ou a modulação do nosso "primeiro movimento". Tudo isso é o dado dialógico básico, sem que se deva necessariamente identificar (o que seria no mínimo problemático) as diferentes instâncias subjacentes aos diferentes movimentos.

Em todo caso, as relações entre "sentido" e "força" (quer se trate de discurso, de gestos ou mesmo de modos de ser) fazem parte do difícil de dizer, mesmo quando não pretendemos dar uma "boa definição" das "grandes palavras" como "psiquismo" e "pensamento", por exemplo, lugar onde supostamente se faria essa união força-sentido.

De qualquer forma (e para ficar na linguagem, na medida em que se pode isolá-la), há, sem dúvida, na maneira mesma pela qual cada um sente a força das palavras de si e dos outros, grandes diferenças de estilo, assim como no modo como tentamos teorizar sobre isso. Parece-me que cada um de nós retoma aqui uma parte do que foi dito, o acentua, por um lado, segundo o espírito da época, por outro, em função de suas próprias orientações ${ }^{6}$, de maneira explícita ou implícita. E esse dito será, por sua vez, explícita ou implicitamente reconfigurado pelo receptor. "Implícito" podendo ademais significar muitas coisas, o óbvio ou o misterioso, o que é familiar ou distante, especialmente o que abre ou não perspectivas. Mas sabemos de antemão o que é "pensar bem” sobre tais problemas? Em todo caso, a palavra "força" é, ao mesmo tempo, familiar e enigmática. Ela nos faz sem dúvida pensar em força física e em suas várias formas. A "força" de um discurso se aproxima desta última, como nas ocasiões em que temos a sensação de que não podemos escapar da coerção do que é dito? A "força” de uma proibição seria desse tipo? Mas é a força do próprio enunciado ou a força decorrente do prestígio, da autoridade de quem disse? Existem, contudo, muitos outros tipos de forças. Assim, no caso da linguagem, haveria, em primeiro lugar, o tipo de força que provém do fato de se partilhar o mesmo sistema de signos: pensemos na conivência daqueles que têm a mesma língua ou os mesmos pontos de referência. Note-se que a força dessa ligação pode ser tão habitual que só nos tornamos conscientes dela quando ela falta e nos sentimos perdidos. Essa ligação pode funcionar como força de uma "grande comunidade", ou ao contrário, como signo de convergência de um subgrupo, seja no caso de uma gíria, de um efeito de moda, de um jargão técnico, de uma marca de pertença a uma religião, a um partido político, ao fato de ser discípulo de A ou B. Há, ao contrário, o aspecto maravilhoso e/ou aterrorizante do choque da revelação de um aspecto desconhecido ou da ruptura do que parecia óbvio e, de modo geral, às forças de coerção poderiam se opor todas as forças do que "faz parecer diferente". Assim, no exemplo da sedução ou da inquietação produzidas pelo sonho como modelo de "literatura espontânea" (mesmo se ele obriga a ampliar o sentido usual de "linguagem").

\footnotetext{
${ }^{6}$ N.T.: Noção proposta por François (2009, p. 10-11), autor que “se opõe a 'aplicar uma regra', 'resolver um problema' ou 'estar completamente perdido'. Aquele que se orienta pode retornar à situação em que está. Ele não está necessariamente 'desorientado'. [...] há situações mais ou menos típicas em que estamos confrontados com a necessidade de nos orientarmos. Podemos partir do 'caso geral' da criança que enfrenta a situação da forma como ela pensa e o que dizem os seus pais. [...] Em nossa vida de adulto, quando somos confrontados à distância entre o que se apresenta para nós na experiência da vida real e tal momento e as considerações gerais, as regras, ou princípios aprendidos”.
} 
Pontalis propôs o termo "força de atração" como título de um de seus livros. E existe, evidentemente, uma força de sedução (mas qual a ligação entre "sedução" e "atração"?) daquilo que nos surpreende. Teria aqui tudo o que poderíamos chamar de "força da alteridade". E haveria também, além da força da coerção, da ascendência, da alteridade, a força de resistência que é o humor, o distanciamento, como força de nossa própria fraqueza. Acrescente-se a isso, contrariamente ao que se passa na "boa transmissão" de informações, o que tem de inevitável no fato de nenhuma "mensagem" ser completamente traduzível e que, em vez disso, o "modo de dizer" opera em nós pelo que tem de surpreendente ou de confuso, na medida em que nos faz pensar além do estritamente dito, justamente pelo seu tom e pelas repercussões que provoca. Todos esses efeitos variam necessariamente em função dos receptores e da disposição deles para receber tal tipo de discurso, para reagir com violência ou sem saber como se orientar em relação a ele. É em torno dessa diversidade de tipos de "sentidos-forças" que poderíamos tentar levantar a questão da cultura e da transmissão cultural...

Estamos, obviamente, muito longe das evidências cartesiana ou espinosista do verum index sui et falsi e da força própria da verdade. Podemos apenas constatar que, assim como não há um só tipo de forças, há mais diferenças do que semelhanças entre a revelação de um encontro, a preocupação em que nos coloca a previsão quando se torna realidade, a verdade do cálculo astronômico e a da reconstituição arqueológica. Em todo caso, é a partir do choque produzido em mim pela leitura dos três autores russos que eu gostaria de orientar minha proposta. Todavia, no caso dos textos de Volochinov e de alguns de Bakhtin, o choque é antigo, mas foi renovado, tanto para certos textos de Bakhtin como para os textos de Vigotski, tendo em vista que minha leitura desse último vai se limitar praticamente àqueles que eu desconhecia, consagrados à vida emocional e, sobretudo, à obra de arte. Tudo isso remete, em todo caso, a uma caracterização (subjetiva) desses três autores como grandes homens: não aqueles que transmitem "verdades", mas ajudam (ou obrigam) a refletir de forma diferente na selva do real, com este paradoxo "dialógico": estamos no fim das contas sempre sós na relação estar perdido/nos orientar e ninguém pode pensar sozinho. Além disso, fui conduzido a utilizar a noção de "momento" (mas não no sentido hegeliano em que um conhecimento final será capaz de colocar em seu lugar cada um dos "momentos" do pensamento). Uma vez que houve choque, faz-se necessário reproduzi-lo, colocá-lo em relação com o resto, com o pensamento indeterminado ${ }^{7}$ ou com a repercussão particular em cada um de nós.

(Proponho aqui a palavra repercussão para indicar que não há diferença "natural" entre perceber, compreender e sentir, mesmo que tenhamos concomitantemente a experiência de que o mesmo objeto pode provocar diferentes modos de repercussão em nós, assim como pode ser percebido de vários pontos de vista).

c) Mas outra ampliação também se impõe. Não se trata só de articular “sentido" e "força", mas de estender "sentido" ao conjunto das atividades do corpo vivo, animal ou humano. Que a interação dos corpos sobretudo na relação adulto-criança é uma fonte primária do sentido tornou-se para nós uma evidência que não era há um século atrás (pelo menos, entre os teóricos). Por exemplo, nos escritos de Wallon, sobre as modificações do sentido do grito na interação entre criança e adultos, ou quando ele lembra como as primeiras manifestações afetivas ocorrem, por exemplo, na altivez ou vergonha, sob o olhar de outrem. Aliás, se é difícil encontrar "fenômenos" humanos que não obedecem a essas mediações, é legítimo buscar, como parece que faz Vigotski, um limite entre funções psíquicas inferiores e superiores? Mas há também a ligação entre a possibilidade de "fazer sentido" e o conjunto dos monumentos, das obras humanas e do modo como eles nos afetam, daí a referência à continuidade-ruptura entre o animal e o homem. Continuidade, porque percebemos melhor do que percebíamos um século atrás o parentesco das relações de apego, de dominação, de jogo entre humanos e primatas. Ruptura, porque somos mais sensíveis à forma como o sentido faz articulação, e o faz através de terceiros que são as instituições e/ou objetos culturais (quer seja o garfo, a rua ou "obras de arte"). Como vemos, por outro lado, que o modo de não perceber ou recusar a cultura dos outros é uma das primeiras formas de violência, cotidiana ou excepcional. Essa ligação entre sentido, obras e cultura evoca a obra de Ignace Meyerson e a necessidade de encontrar o "sentido" entre nós, nossos outros e nosso mundo, e não na interioridade ou intencionalidade.

d) Parece-me que um outro quadro preliminar é constituído de tudo que a fenomenologia e/ou a hermenêutica nos leva a estabelecer sobre a pré-compreensão, anterior à explicitação teórica. Nossa presença no mundo, no tempo, nos outros, nas obras, o modo como nosso corpo e nosso pensamento se orientam existem bem antes do exercício do pensamento discursivo ou verbal. Além disso,

${ }^{7}$ N.T.: Trata-se aqui do pensamento do "on" francês que pode ser traduzido em português por "se", utilizado como índice de indeterminação do sujeito, ou ao "eles", sem referência a nenhum termo identificado anteriormente, no caso dos sujeitos indeterminados, com o verbo na terceira pessoa do plural. 
ninguém é capaz de distinguir em si o que é genérico ou particular no seu modo de presença no mundo. Não mais aliás do que o modo de pensar, como mostra a multiplicidade de maneiras de descrever, de colocar em perspectiva ou a diferença que existe entre a nossa capacidade de reagir negativamente a uma explicação quando sentimos que "não é bem assim" e nossa habilidade positiva "para descrever corretamente".

Mas a questão que se coloca então é sobre a diferença que existe entre evocar essa multiplicidade de aspectos e a possibilidade de efetivamente dar conta dela. Saímos, de modo geral, dos modelos estruturalistas redutores. Mas cada um não está limitado a seus objetos como a seus estilos de abordagem, sendo o "resto" mencionado no horizonte, mas não elucidado de fato? O que poderia talvez levar a uma reflexão sobre a forma como os textos que se definem como filosóficos ou científicos estão sujeitos à mesma variação inevitável de "pontos de vista” que os textos "literários”.

e) Ademais, parece que as obras foram analisadas em função de suas condições de produção. Mas o que caracteriza, em geral, os textos que lemos é que não poderíamos produzi-los. E isso é constitutivo do efeito desses textos em nós. Gostaria de acrescentar que considero que não se pode dizer quase nada sobre os processos de elaboração das obras e que há sempre um risco de falar de "obras" como se tivéssemos acesso às "obras em si". O que pode ser analisado é, sobretudo, nosso processo de leitura, sempre com a dificuldade de discernir o que na nossa leitura é parte de um "nós” mais ou menos intercambiável.

f) Um desafio final. Não podemos não nos situar numa filiação, numa relação com o pensamento dos outros e, especificamente, dos nossos "pais". E, ao mesmo tempo, esse alinhamento tem sempre algo estranho. É assim quando se invoca uma escola bakhtiniana ou vigotskiana? Com todas as querelas (cômicas?) que isso acarreta para saber quem são os melhores "filhos"?

Para não personalizar a questão, parece-me que, de qualquer modo, não é possível ser simplesmente "filho de": toda "transmissão geracional" é também modificação. O que é magnificamente revelado no caso dos filhos de Freud ou de Marx, mas se encontra igualmente em outras filiações, sobretudo porque a paternidade cultural, felizmente, é mais partilhada que a paternidade da procriação corporal e que, correlativamente, não há algo de unívoco que seria a perspectiva de tal escola ou de tal indivíduo.

O objetivo aqui não é, como no início de algumas teses, apresentar um “estado da arte”, o que dá geralmente uma configuração com certeza objetiva, mas bastante lamentável do "pensamento dos outros". Assim, o que não tem repercussão direta em nós não é, no entanto, anulado. Para dar um exemplo mais grosseiro: não temos, parece-me óbvio, a perspectiva revolucionária imediata que dominava nos anos 1920, de substituir a sociedade capitalista por uma sociedade socialista, acabando com a luta de classes. Isso não elimina o pensamento ou o sonho, se não de um "homem total" ou de um "homem reconciliado", mas de uma sociedade onde, pelo menos parcialmente, a violência da exploração teria sido dominada. Nesse ponto, estamos ao mesmo tempo próximos e distantes de nossos "grandes antepassados".

De todo modo, eu não gostaria de aproveitar minha relação provisória de vivo com autores mortos para "colocá-los em seu lugar", mas, ao contrário, para destacar o que provocou em mim um choque na leitura desses autores, esperando conseguir transmitir um pouco desse choque, e fazer dele uma ligação, questionando um pouco o que nos serve de "pano de fundo" discursivo habitual. "Choque", "articulação" e "pano de fundo" (cada uma dessas noções pode ser, por sua vez, pluralizada) parecem ser três aspectos do que pode ser livremente agrupado na noção bastante vaga de "sentido".

g) O que leva à última observação introdutória: no campo geral do que o termo abrange, e devido à sua repetição, "dialogismo" corre sempre o risco (como todas as grandes noções) de não querer dizer mais nada. Parece-me que os três autores mencionados no título propõem algo em comum: considerar primeiro os "pensamentos" como "signos" significa dizer que o pensamento não está primeiramente em nós, mas entre nós, sobre a base contraditória do que nos aproxima e de nossa heterogeneidade (em relação a nós mesmos e aos outros). Aqui "dialogismo" não se refere apenas à diferença de "vozes", mas à heterogeneidade fundamental das formas de sentido, seja, por exemplo, a oposição feita por Bakhtin entre monologismo e plurilogismo, seja a apresentada por Volochinov entre "língua materna" e "língua estrangeira". Finalmente, no caso de Vigotski, vou me debruçar não sobre o que é bem reconhecido - o que há, de certa forma de acidental, no encontro do pensamento e da linguagem - mas sobre a tensão, fonte do efeito próprio da recepção estética, entre a fábula, o conteúdo e o sentido produzido pela organização formal do texto.

François | Trad. Cunha | Dialogismo das "vozes" e heterogeneidade constitutiva do sentido. o "literário"... 
Trata-se, portanto, de me orientar (e não de desenvolver um "conhecimento") em um campo bastante opaco e, especialmente, heterogêneo, repleto de já-ditos, de práticas múltiplas e de questões urgentes. O que dizer, então, de um diálogo a três (pelo menos) que é efetivamente a relação entre os textos, os adultos como mediadores e os modos de leitura que podem fazer os "mais jovens"? Partimos da observação da diferença entre as evidências das gerações, as evidências de cada um e os hipotéticos elementos de "terreno comum da humanidade", estabelecendo uma relação aleatória, base do aspecto aleatório do diálogo, especialmente porque não há um discurso do saber que diria com certeza o que é "verdadeiramente importante" nessas semelhanças e nessas diferenças. Podemos apenas constatar que noções tradicionais como a de cultura, de legado ou de transmissão se tornaram problemáticas e que não vemos que solução teórica poderíamos dar aqui.

A questão que se coloca especialmente aqui é a da ligação do que faz "nossa realidade" e do que aparece por meio dessas obras. Seria o caso, por exemplo, de a ficção ser apenas "distante da realidade" ou ao contrário a leitura de tal obra é uma via (ou a via) pela qual alguns aspectos do "real" se manifestam para nós? Podemos fazer a estranha constatação de que contamos histórias às crianças, que "temos prazer" (algumas vezes) em ler, que uma vulgata supõe que é necessário "ser culto" e que isso ocorre por meio da leitura, mas nunca se sabe muito bem qual é a relação entre leitura-prazer, leitura-cultura e a nossa vida como um todo, nem se sabe também de forma mais clara o que é a suposta "cultura erudita". Será que há alguma obrigação para nós de apresentar aos alunos um determinado autor e por que razão? Parece-me - e é, espero, uma das justificativas deste ensaio - que Bakhtin, bem como Vigotski, tenta identificar o que há de específico no modo de agir da forma literária, que faz a realidade repercutir em nós diferentemente do que ela aparece em outras formas de mediações. Mas dizer isso não invalida a questão da diversidade de leituras de uma mesma obra. Aqui o dialogismo corre o risco de se transformar em babelismo. Isso porque o "textual” não pode ser considerado por si só, porque ele é "por natureza" referência ao extratextual e isso, ademais, no modo não determinado da alusão. O textual é algo "fechado" em relação a um "aberto", que não pode jamais ser atualizado completamente. Assim, enquanto estamos interessados no explícito do texto, podemos concordar; no momento em que nos interessamos ao que ele remete de modo não explícito, tudo muda. Certamente há o saber supostamente partilhado (cuja explicitação tem um papel importante na vida escolar). Mas há inversamente a diferença de nossos modos de reação. E é impossível pressupor que apenas o comum é essencial, o diferente sendo acidental. É precisamente uma das características da obra literária: fixar a realidade flutuante das diferenças, e, principalmente, dar uma forma quase estável aos "mundos" ou aos "outros”, cuja variabilidade e indeterminação habitam as profundezas de cada um de nós.

Daí, o foco deste texto em três aspectos:

- a noção de "ideologia do cotidiano" de Volochinov e sua relação com a língua da cultura como língua estrangeira;

- o estabelecimento de um "dialogismo irredutível" de Bakhtin;

- a teoria da arte e sua ligação com a teoria da emoção de Vigotski.

Um dos pontos em que há convergência dos três autores é que os textos (literários, em particular) não são formas da "língua" em sua abstração, mas se diferenciam em gêneros sociais diversos. Foi Bakhtin quem postulou a oposição em "gêneros primários" e "gêneros secundários”, mas essa distinção é mais ou menos explícita nos outros dois. Pareceu-me que esse ponto era suficientemente conhecido para não se voltar a ele aqui.

Poderíamos ter feito um vaivém entre os temas dos três autores. Mas haveria o risco de ser o manipulador de marionetes, o todopoderoso monologista temporariamente vivo, que faz dialogar os mortos. Preferimos uma concepção mais "pedagógica" num sentido mais modesto do termo. Lembraremos inicialmente alguns aspectos do pensamento de Volochinov, limitando-nos a alguns pontos principais: em primeiro lugar, algumas palavras sobre a vontade de "materialismo" de Volochinov; em seguida, a elaboração da noção de "ideologia do cotidiano" que ele apresenta como sendo o modo como nosso espaço mental é tecido, como lugar em que "a cultura" encontra nossa vida. Depois, algumas palavras sobre o papel da "língua estrangeira" na constituição da cultura. Por fim, deixo de lado como pano de fundo as considerações polêmicas sobre o materialismo, Freud ou contra o subjetivismo humboldtiano e o estruturalismo. Exceto para lembrar que o texto de Volochinov propõe de modo bastante claro não opor simplesmente "língua" e "fala", mas buscar constantemente o jogo entre linguagem "indeterminada", linguagem do "outro" e "nossa" linguagem.

${ }^{8}$ N. T. : Langage de “on”. Ver nota 9. 
Como se trata aqui principalmente da cultura, tal como ela é trazida pela literatura, era natural que Bakhtin fosse colocado no centro da discussão. Poderíamos ter separado os textos de Bakhtin contemporâneos dos de Vigotski e, depois de falar de Vigotski, retornar aos últimos textos de Bakhtin. Mas ao meu ver há uma unidade do pensamento de Bakhtin (mais uma vez posso estar enganado), que será apresentada em três aspectos. Primeiro, uma breve visão de uma filosofia muito geral das ciências humanas, da estética e de sua relação com a ética, ou com a vida real de cada um de nós (tanto em textos de 1920-1930 como em textos mais tardios), bem como da distinção entre "gêneros primários" e "gêneros secundários" e da possível retroação dos segundos sobre os primeiros. Em seguida, observações sobre a relação entre o autor e o herói (ou a obra). Finalmente, alguns aspectos do seu pensamento sobre o tema mais conhecido, me parece, da oposição monologismo-dialogismo, ilustrada pelas figuras de Rabelais e Dostoiévski.

Apresentarei, para encerrar o quadro teórico do pensamento estético, algumas observações de Vigotski (não o conjunto dos livros que ele dedicou a esse tema) sobre a relação entre as emoções, os sentimentos e a cultura, insistindo especialmente em seu trabalho sobre a obra de arte, que me parece ao mesmo tempo original e menos conhecido.

2 ALGUNS ASPECTOS DO PENSAMENTO DE VOLOCHINOV, sob os quatro aspectos do que pode ser chamado de violência materialista: a introdução da problemática da ideologia e da ideologia do cotidiano, o papel da "língua estrangeira" e finalmente o que é dito (muito próximo de Bakhtin) sobre a heterologia fundamental da linguagem.

a) Sobre os dois primeiros pontos, começo lembrando algumas citações do livro O freudismo de Volochinov. Primeiro, porque sua publicação é anterior a do livro Marxismo e filosofia da linguagem, publicado em 1929 (os dois textos da edição francesa do Freudismo foram publicados originalmente em 1925) ${ }^{9}$. E porque Volochinov, especialmente aqui, se coloca como marxista e materialista, mais do que Vigotski, que discute com a tradição psicológica alemã, sem parecer, na maioria dos casos, que o "marxismo" toma conta do seu discurso, e mais do que Bakhtin, cuja referência ao marxismo é discreta, até mesmo reticente, em todo caso, menos explícita do que a que ele faz à figura de Cristo. Ele o faz enfatizando pelo menos quatro pontos:

- Primeiro, a necessidade de levar em conta o lugar dos homens na sociedade, no que ele critica Freud, com razão a meu ver, por não o fazer.

- Em seguida, referindo-se à reflexologia como a única parte da psicologia verdadeiramente materialista de fato desenvolvida. Pode-se notar aqui o interesse da crítica de Volochinov à noção freudiana de "inconsciente". Ele a critica porque esse "inconsciente" é constituído a partir da divisão tradicional em pulsões, sentimentos, representações, "o que significa que se lhe dá uma estrutura análoga à da consciência, e isso até mesmo nos mínimos detalhes" (Bakhtin, 2007, p. 50). Imagino que os freudianos responderiam que o principal para eles é a oposição dos processos primários e secundários, que introduz uma diferença real, mas isso nos remeteria à questão de saber se são duas instâncias ou duas formas de pensamento constantemente entrelaçadas, como quando, ao mesmo tempo, uma pessoa é identificada (processo secundário) pelo seu papel social atual e (processo primário) porque ele nos faz pensar sobre o modo como ela age em nós.

Sabemos que Volochinov desenvolve a noção, original para mim, de "ideologia do cotidiano": "Chamamos discurso interior e exterior a 'ideologia do cotidiano' que penetra integralmente o nosso comportamento. Em certos sentidos, essa ideologia do cotidiano é mais sensível, compreensiva, nervosa e móvel que a ideologia enformada 'oficial”' (Bakhtin, 2007, p. 88-89). Mas Volochinov acrescenta que ela obedece às mesmas leis que a ideologia externa. "O sonho, o mito, a brincadeira, o gracejo e todos os componentes verbais das formações patológicas refletem a luta de diferentes tendências e correntes ideológicas que se constituíram no interior da ideologia do cotidiano."

- Ao mesmo tempo, Volochinov tenta caracterizar a tomada de consciência:

\footnotetext{
${ }^{9}$ N.T.: A edição francesa intitulada Le freudisme, atribuída unicamente a Bakhtin, contém dois ensaios: "Au-délà du social. Essai sur le freudisme" e "Le Freudisme. Essai critique”. A edição brasileira, também atribuída a Bakhtin, traz apenas o segundo (Bakhtin, M. O freudismo: um esboço crítico. São Paulo, Perspectiva, 2007). O primeiro ensaio, Para além do social, foi publicado na coletânea Volochínov, V. N. A construção da enunciação e outros ensaios. São Carlos, Pedro \& João Editores, 2013. As citações são da edição brasileira.
} 
Ao tomar consciência de mim mesmo, eu tento como que olhar para mim com os olhos de outra pessoa, de outro representante do meu grupo social, da minha classe. Desse modo, a autoconsciência acaba sempre nos levando à consciência de classe, de que ela é reflexo e especificação em todos os seus momentos essenciais, basilares. (BAKHTIN, 2007, p. 87)

O que parece ir de encontro à apresentação anterior da ideologia do cotidiano. Mas o que é certoé que Volochinov parece considerar como óbvia a identificação da consciência a uma consciência de classe, o que é para mim (para nós?) no mínimo opaco. Um pouco mais tarde, Volochinov apresenta de forma um pouco diferente o futuro de nossa consciência:

Quanto mais claro se torna meu pensamento, tanto mais ele se aproxima dos produtos enformados da criação científica. Além do mais, meu pensamento não consegue atingir a clareza definitiva enquanto eu não lhe encontro uma formulação verbal precisa e não o associo àquelas teses da ciência que dizem respeito ao mesmo objeto, ou melhor, enquanto eu não transformo o meu pensamento em uma obra científica importante. (BAKHTIN, 2007, p. 87)

Essa capacidade de transformar em ciência o conteúdo da nossa consciência me deixa cético. Sobretudo porque Volochinov acrescenta: "Um sentimento qualquer não pode atingir maturidade definitiva e precisão sem encontrar a sua expressão externa, sem fecundar palavras, ritmo, cores, isto é, sem tomar a forma de uma obra de arte" (Bakhtin, 2007, p. 87). O que é muito bonito e menos estranho no imediato, mas supõe também que há de um lado o pensamento, de outro o sentimento, numa dicotomia que ele parecia criticar acima e que não permite pensar em obras de arte que não são conceito ou sentimento (me parece) não muito diferente do que transmite aliás a tradição religiosa. O fato é que, para nós, de modo mais difícil ainda de compreender, Volochinov menciona o papel das contradições sociais. Ele nos diz então que "em um grupo sadio, e num indivíduo sadio, a ideologia do cotidiano fundada na base econômico-social, é integral e forte: não há nenhuma divergência entre a consciência oficial e a não-oficial”10 (BAKHTIN, 2007, p. 89). Os desenvolvimentos de Volochinov vão aqui em diferentes direções e sentidos:

Existe um campo sumamente importante do comportamento humano, em que os contatos verbalizados se estabelecem com grande dificuldade e por isso ele escapa de modo especialmente fácil do contexto social, perde a sua forma ideológica, degenera no estado animal primário. É o campo sexual. A decomposição da ideologia oficial se reflete antes de tudo nesse campo do comportamento humano. Torna-se centro de acumulação de forças associais e antissociais. (BAKHTIN, 2007, p. 90)

A diferença de nossas evidências faz com que quase paremos em cada enunciado de Volochinov:

- Falar adequadamente do sexual é certamente difícil. E não é a multiplicidade de divulgações científicas que nos envolvem que levam a pensar o contrário, especialmente quando se reconhece que a especificidade do pensamento freudiano é de ter construído o conceito difícil de sexualidade infantil e de sua persistência em todos.

- Mas, por outro lado, o controle social se exerce de outras maneiras além da linguagem. E perguntas sobre a articulação entre normalização da existência sexual e manutenção dos problemas centrais da vida sexual (e/ou afetivo-sexual) permanecem.

- Os "desvios antissociais sexuais", se há algo que podemos chamar assim, certamente não vão na direção da "animalidade primitiva”.

Entretanto, o que faz funcionar para nós o texto de Volochinov não é o "complexo" constituído pela mistura de sua violência simplificadora e pela mudança de perspectiva que consiste em não mais falar em ideologia de modo geral e ainda menos da linguagem em geral, mas da questão das relações entre a ideologia do cotidiano e a ideologia pública em um psiquismo permeado pela vida social?

${ }^{10}$ N.T.: Os itálicos nas citações são do autor russo. 
Por isso, considero que há interesse na crítica dirigida a Freud de não considerar sua própria situação social nem os diversos modos como funciona a consciência, particularmente nos conflitos entre o analista e o analisando como sendo mais "reais" do que os conflitos "internos". Aqui Volochinov antecipa o que será dito sobre as relações entre transferência e contratransferência?

O texto de Volochinov pode conter uma visão simplificada da relação do indivíduo e da sociedade, no entanto, contém duas críticas fundamentadas de Freud. A primeira é que Freud não leva em conta a sua própria situação social. A segunda é relativa à amplitude da noção de inconsciente, como máquina para explicar tudo, correlativa de uma ausência de análise do que é "consciente".

Volochinov questiona-se ao mesmo tempo sobre a distinção entre teoria e prática: a realidade da análise, diz ele, é a luta entre o psicanalista e seu paciente, luta que ele apresenta como conflito entre as não palavras do paciente e as palavras do analista. É esse conflito que é real, enquanto os conflitos que pretendem ser explicativos têm o inconveniente de falar de um pai e de uma mãe sem levar absolutamente em conta as relações sociais.

Deve acrescentar-se que a análise da "ideologia do cotidiano", tanto interna como externa ao psiquismo, é mais desenvolvida em Marxismo e filosofia da linguagem. Texto posterior, influência de discussões (com Bakhtin?), mais espaço? Não sei.

Volochinov dá, no capítulo 1, um conteúdo muito amplo à "ideologia" e ao "signo", postulando que toda ideologia é signo e, sobretudo, que todo objeto material pode também funcionar como signo. Correlativamente, ele postula que só há consciência no que pode aparecer como "signo". Acrescenta finalmente que a palavra é o único material semiótico universal, embora música, pintura ou ritual não possam ser reduzidos ao discurso. A palavra é então caracterizada pela sua pureza semiológica (os outros signos não são apenas signos) e sua onipresença social (BAKHTIN/VOLOCHINOV, 1995, p. 41).

É no terceiro capítulo ("Filosofia da linguagem e psicologia objetiva") que aparece o centro do pensamento de Volochinov: a expressão psíquica pode ser interior ou exterior, mas, de todo modo, é de natureza "semiótica".

O que é que constitui o material semiótico do psiquismo? Todo gesto ou processo do organismo: a respiração, a circulação do sangue, os movimentos do corpo, a articulação, o discurso interior, a mímica, a reação aos estímulos exteriores (por exemplo, a luz), resumindo, tudo que ocorre no organismo pode tornar-se material para a expressão da atividade psíquica, posto que tudo pode adquirir um valor semiótico, tudo pode tornar-se expressivo. (BAKHTIN/VOLOCHINOV, 1995, p. 52)

Esse trecho é evidentemente rápido, deixa sem explicação a questão do "expressivo para o outro" e do "expressivo para si”. Entretanto, acrescentando ao que foi dito acima, a saber que todo objeto "real" é, ao mesmo tempo, signo, tem-se uma articulação entre corporal e signo assim como relação social e signo: "Mas, é certo que sem uma orientação social de caráter apreciativo não há atividade mental". Como mostra o exemplo, que diz que é em função do lugar social que a fome se torna queixa, resignação ou revolta (BAKHTIN/VOLOCHINOV, 1995, p. 114). E ele acrescenta:

É verdade que nem todos estes elementos têm igual valor. Para um psiquismo relativamente desenvolvido, diferenciado, um material semiótico refinado e flexível é indispensável e, por sua vez, é preciso que esse material se preste a uma formalização e a uma diferenciação no meio social, no processo de expressão exterior. É por isso que a palavra (o discurso interior) se revela como o material semiótico privilegiado do psiquismo. É verdade que o discurso interior se entrecruza com uma massa de outras reações gestuais com valor semiótico. Mas a palavra se apresenta como o fundamento, a base da vida interior. A exclusão da palavra reduziria o psiquismo a quase nada, enquanto que a exclusão de todos os outros movimentos expressivos a diminuiriam muito pouco. (BAKHTIN/VOLOCHINOV, 1995, p. 52)

Tais avaliações gerais me deixam preocupado. Parecem ignorar tudo o que de nossos modos de ser, de fazer, de sentir fica à margem da linguagem, difícil de dizer, ou até necessariamente mal formulado. O mundo do corpo deitado e do corpo em pé, andando ou

François | Trad. Cunha | Dialogismo das "vozes" e heterogeneidade constitutiva do sentido. o "literário"... 
agindo; só ou em grupo ou a prontidão ${ }^{11}$, de que nos fala Wallon. Há aí uma diversidade de relações aos outros e a si que excede as "relações de classe". E todas essas modalidades me parecem caracterizadas por formas de consciência-inconsciência, sobressemiotizações ou pensamentos que podem ser sempre revistos. Falar de "falsa consciência" significaria que sabemos o que é uma "consciência verdadeira" ou adequada. É esse o caso? Nossas formas de tomadas de consciência são necessariamente limitadas, como a que opõe minha relação ao que sinto, ao que digo sobre isso, ao que me diz o outro, ao que eu apreenderei mais tarde. Cada um reconhece por exemplo que o que percebia como "naturalmente" não era tão natural assim ou que agora faria de outra forma. Não se trata de substituir um erro absoluto por uma verdade absoluta. Contudo, ao mesmo tempo que falar sobre o objeto (complexo, é verdade) da "ideologia do cotidiano" como relação entre sentido corporal e sentidos sociais, especialmente verbais, continua sendo uma forma que me parece legítima de colocar o problema da ligação entre corpo-sociedade-sentido, é possível se questionar sobre a supervalorização da linguagem em relação a tudo o que caracteriza nossas maneiras de ser, sentir ou fazer sem ser dito. E, especialmente, em relação a tudo o que na nossa relação ao mundo, aos outros, a nós mesmos inclui a linguagem, mas não se limita a esse aspecto linguageiro. Parece-me que, assim como o corpo do animal só existe pela sua relação com seu Umwelt, da mesma forma é primeiramente o nosso corpo que faz com que estejamos cercados de um universo de valores, sedutor, neutro, ameaçador, e que tudo isso é experimentado antes de ser dito. É verdade, evidentemente, que o dizer estenderá os limites do que é sentido para longe, ao mesmo tempo que a tonalidade específica desse sentir resistirá ao processo de elaboração do discurso. Com a multiplicidade das relações entre semióticas discursivas e outras semióticas: o que se sente com uma música resiste a um discurso "adequado" tanto quanto a visão de um rosto? O que não impede que a linguagem seja o principal meio da presença em nós de um longínquo e/ou da alteridade dos pensamentos dos outros. Se bem que analisar o que passa pela linguagem é analisar ao mesmo tempo o que resiste ou o que a linguagem necessariamente modifica para poder dizer.

b) Algumas palavras agora sobre o que me parece se integrar mais particularmente a uma "teoria literária" no sentido amplo: a questão da articulação entre a língua materna e língua estrangeira. No Capítulo 5, “A linguagem, língua e fala”, a palavra estrangeira aparece pela primeira vez como a palavra escrita, objetivizada pela filologia, o oposto da palavra viva. Mas, ao mesmo tempo, "a palavra da língua nativa é percebida como um irmão, como uma roupa familiar, ou melhor, como a atmosfera na qual habitualmente se vive e se respira..." (BAKHTIN/VOLOCHINOV, 1995, p.100). A palavra da língua estrangeira, ao contrário, faz pensar.

A palavra estrangeira é central no desenvolvimento de qualquer cultura "em todas as esferas da criação ideológica, sem exceção, da estrutura sociopolítica até o código de boas maneiras" (BAKHTIN/VOLOCHINOV, 1995, p. 101). Volochinov evoca os sumérios face aos semitas babilônicos, os jaféticos (vemos que Marr não está longe) face aos gregos e outros:

Esse grandioso papel organizador da palavra estrangeira [...] fez com que na consciência histórica dos povos, a palavra estrangeira se fundisse com a ideia de poder, força, santidade, verdade e obrigou a reflexão linguística a voltar-se de maneira privilegiada para seu estudo. (BAKHTIN/VOLOCHINOV, 1995, p. 101)

O que é, simultaneamente, criador e alienante, uma vez que ele acrescenta que o objetivismo abstrato da linguística da palavra "reflete a posição da palavra estrangeira no estágio em que ela já perdeu, numa larga medida, seu caráter autoritário e sua força produtiva" (BAKHTIN/VOLOCHINOV, 1995, p. 105, nota de rodapé 11).

Mas, para tentar justificar o que nos seduz na "literatura" considerada em sua generalidade, não poderíamos dizer que ela fica entre os dois polos do calor da língua materna e do fascínio de língua estrangeira, e que, alternativamente, inquieta e faz pensar? Pode-se encontrar a ligação entre esses dois aspectos na análise que faz Bakhtin do escárnio da língua de Rabelais como caricatura da linguagem de autoridade. Como é um aspecto central da situação, especialmente agora, da linguagem da escola, ser tomada, tanto no plano do discurso do saber como do discurso literário, entre duas linguagens. Mas se constatarmos que desde a antiguidade houve comentaristas dos textos sagrados, talvez devêssemos reconhecer que a instituição escolar continua a ter o seu papel tradicional de intermediária, como, correlativamente, ritmos e falas “populares" alimentam a literatura e a música "erudita”. Decorre daí a questão da possibilidade ou não de se fazer uma clara distinção entre obras de elite, obras populares e obras por natureza transclasses, tanto nos romances e filmes quanto na religião.

${ }^{11}$ N.T.: Prestance em francês, noção que é traduzida por prontidão, presença ou predisposição. 
c) Não vou me deter, portanto, na crítica das dicotomias saussurianas, como na questão de saber se a leitura crítica de Saussure se dirige ao "verdadeiro Saussure". Queria apenas lembrar que a última parte do livro de Volochinov é uma verdadeira revolução teórica, uma vez que coloca no centro do estudo "técnico" da linguagem o do discurso reportado, e não o das estruturas da língua, nem o da unidade da mensagem, mas o contraste entre a voz de quem reporta e aquela, subjacente e distorcida, dos dizeres relatados. A unidade de partida não é mais a língua, mas os discursos em que se misturam continuamente o mundo visto pelo autor, pelos outros, os comentários, as hesitações do herói, o que nos leva diretamente à visão bakhtiniana do romance, tecido não só de diferentes tipos de discurso, mas de perspectivas incompatíveis da mesma realidade. (Faltaria determinar sob a forma de influência e em que sentido se pode explicar a maior proximidade, aqui, entre os textos de Volochinov e os de Bakhtin.)

Gostaríamos ainda de dizer algumas palavras sobre a diferença dos pensamentos de Volochinov e de Marr. Mas lembrar primeiramente com Sériot a estranheza do pensamento de Marr como indica o título de seu artigo "Se Vico tivesse lido Engels, ele se chamaria Nicolas Marr": trata-se de traçar uma história global do pensamento. Partindo de um primeiro estágio onde o pensamento da humanidade era principalmente corporal, especialmente em cerimônias religiosas, em uma linguagem manual e, em seguida, cantada, ideia comum no século XVIII, a Vico, Rousseau e Condillac, o surgimento da linguagem verbal está relacionado com a separação dos grupos dominantes e dominados, essa divisão devendo desaparecer permanentemente para uma linguagem definitivamente livre da matéria sonora, língua técnica exclusiva da sociedade sem classes. Mas o que caracteriza o pensamento de Volochinov (que cita bastante Marr sem criticá-lo) não é considerar que cada classe teria sua língua, mas que cada grupo social (ou cada um que fala em seu nome) reacentua ao seu modo as palavras comuns. Se pensarmos no nosso cotidiano, basta olhar as lutas atuais para a reapropriação e a reavaliação de termos como "reforma", "flexibilidade”, "globalização", "jovem”, etc. para ver claramente que é isso que ocorre. Há aqui "ideologia dominante" que se encontra nas palavras de cada um, em sua "ideologia do cotidiano", na qual, em última análise, aquela nem sequer precisa ser afirmada.

\section{ALGUMAS CARACTERÍSTICAS DO PENSAMENTO DE BAKHTIN}

Gostaria de continuar minha exploração com Bakhtin, focalizando, como anunciado, dois aspectos muito diferentes: por um lado, sua teoria da distância entre ciência, ética, estética e religião e, correlativamente, da "exotopia" do autor, e por outro lado, sua reflexão sobre a diversidade cultural e as várias figuras do "dialogismo".

a) A permanência do problema (kantiano?) da divisão ciência-ética-estética-religião e a "exotopia” do autor.

Há uma constante no pensamento de Bakhtin: a irredutibilidade desses quatro domínios, tipos de relação com a vida, consigo mesmo, com os outros. Embora, naturalmente, a obra de arte refira-se constantemente às três outras dimensões. No entanto, essa convicção pessoal de Bakhtin tem consequências diretas na análise do romance. Esse não é um trabalho de "ciência" legal, experimental. Mas, ao mesmo tempo, enquanto nossa perspectiva moral está necessariamente ligada à nossa orientação para o futuro, na obra literária, tragédia antiga ou romance, o destino do herói é necessariamente acabado, visto do exterior como um todo.

É no texto "O autor e a personagem na atividade estética"12 publicado em Estética da criação verbal (1920-1930, não publicado na época) que Bakhtin desenvolve o tema da exotopia, da relação do autor com o herói, da distância obrigatória entre eles.

Este texto é dividido em três partes consagradas ao espaço, ao tempo e à totalidade do herói. Só existe obra porque as perspectivas não coincidem, porque o autor pode totalizar o herói, saber mais do que ele.

Do ponto de vista do espaço, a exotopia manifesta-se no fato de que ninguém pode se ver como os outros o veem e somente aqueles outros o totalizam. Tanto do ponto de vista estético quanto do ponto de vista ético, Bakhtin opõe-se (como faz Scheler) a uma teoria

${ }^{12}$ N.T.: A tradução francesa e Frédéric François usam o termo herói. Utilizamos personagem apenas nas citações da tradução brasileira, feita por Paulo Bezerra na edição de 2003 de Estética da Criação Verbal.

François | Trad. Cunha | Dialogismo das "vozes" e heterogeneidade constitutiva do sentido. o "literário"... 
da identificação. Em termos de ética, porque "quando me compenetro dos sofrimentos do outro, eu os vivencio precisamente como sofrimentos dele, na categoria do outro, e minha reação a ele não é um grito de dor, e sim uma palavra de consolo e um ato de ajuda" (BAKHTIN, 2003, p. 24). Da mesma forma, no plano estético, o outro é percebido em sua exterioridade, em sua exotopia, e não em sua própria perspectiva: "E todos esses valores que concluem a imagem dele, eu os hauri do excedente da minha visão, da minha vontade e dos meus sentimentos" (Bakhtin, 2003, p. 25). No geral, esse ponto é resumido no final do texto de Bakhtin. Não é apenas uma questão de forma, de estética no sentido estrito:

O artista nunca começa desde o início precisamente como artista, isto é, desde o início não pode operar apenas com elementos estéticos. Duas leis guiam uma obra de arte: a lei da personagem e a lei do autor, uma lei do conteúdo e uma lei da forma. Onde o artista opera desde o início com grandezas estéticas, tem-se uma obra feita, vazia, que não supera nada e, no fundo, não cria nada de axiologicamente ponderável (BAKHTIN, 2003, p. 183).

O herói não pode ser criado. Ele tem sua própria lei.

É essa relação de exotopia que faculta a um herói ser trágico: não é o fato de sofrer que é trágico, mas o fato de que esse sofrimento apareça de fora como destino impondo-se ao personagem. Como há sempre uma tensão entre o horizonte (o mundo tal como foi apreendido pelo herói) e o entorno (o mundo como é visto pelo autor ou por terceiros). Que os mundos percebidos por mim, por este outro ou pelos outros em geral não possam coincidir pode ser visto aqui como a forma universal (e nunca realmente superável) de "dialogismo" enquanto teoria do conflito inevitável. Há em todos nós oposição entre o horizonte não tematizado e os objetos visados ou (supostamente) conhecidos, o que faz aliás com que a noção de contextualização indique mais um problema do que uma solução.

Em relação ao tempo como dimensão da subjetividade, Bakhtin insiste no fato de que a unidade da "alma” da personagem não é, obviamente, o que nos dá a psicologia que se quer científica, mas também não é o que nos apresenta a perspectiva ética voltada para o futuro: só a vida do outro pode ser totalizada. Para usar uma antecipação, encontramos a ideia de Sartre de má-fé daquele que fala de si como por índole ou destino. Um ponto em que tenho mais dificuldade:

Consequentemente, $\mathrm{o}$ ato criador (o vivenciamento, a aspiração, a ação) que enriquece o acontecimento da existência, (o enriquecimento do acontecimento só é possível por via qualitativa, formal, e não quantitativa, material, se ele não se transforma em qualitativo) e cria o novo, é, essencialmente, extrarrítmico (em sua realização, evidentemente; uma vez realizado, ele passa para a existência: em mim mesmo, em tons de arrependimento; no outro, em tons heroicos). (BAKHTIN, 2003, p. 108)

O livre arbítrio e o ativismo são fatos incompatíveis com o ritmo. "A vida (o vivenciamento, a aspiração, o ato, o pensamento) vivenciada nas categorias de liberdade moral e ativismo não pode ser ritmada" (BAKHTIN, 2003, p. 109). Aqui, Bakhtin parece referir-se ao ato moral no momento da escolha. Mas ele acrescenta:

É verdade que a não liberdade, a necessidade da vida enformada pelo ritmo não é uma necessidade (cognitiva) malévola nem indiferente ao valor, mas uma necessidade bela, doada, concedida pelo amor. A existência ritmada visa a uma "finalidade sem fim", o fim não é escolhido, discutido, não há uma responsabilidade pelo fim; o lugar ocupado pelo todo esteticamente percebido no acontecimento aberto da existência única e singular não é discutido, não faz parte do jogo. (BAKHTIN, 2003, p. 109)

O que nos leva à questão da heterogeneidade (relacionada às três críticas kantianas?) dos três domínios da estética, da ciência e da moral. O homem moral é aqui apresentado como homem só, reduzido à sua consciência. É claro que o respeito pela palavra dada, pelo compromisso vão contra as alternâncias de nosso modo de sentir. Bakhtin lembra que o que caracteriza nossa relação (moral) com a nossa própria vida é a orientação para o futuro,

[...] só a consciência de que ainda não existo no essencial é princípio organizador da minha vida vivenciada por dentro de mim (em minha relação comigo) [...] Não aceito a minha presença; acredito insensata e inefavelmente em minha não-coincidência com esta minha presença interior. Não posso calcular a mim mesmo inteiramente, 
afirmando: aqui estou, eu inteiro e não existo mais em parte alguma e em nada, já sou integralmente. (BAKHTIN, 2003, p. 116)

Em vez disso, Bakhtin introduz uma teoria da alma como uma teoria da limitação pelo outro como fabricação de um objeto ritmado, estético, como é estético o acabamento da vida representada na morte. "O ritmo abrange a vida vivenciada, nas cantigas de ninar já começam a ecoar os tons do réquiem do fim” (BAKHTIN, 2003, p. 121). E o final do texto mostra que há uma contradição que é o próprio objeto da estética do romance: "aqui se situa o ponto da suprema tensão do ato criador de cada artista [...] em sua criação, desde que ele [...] e lute contra o elemento ético-cognitivo cru da vida" (BAKHTIN, 2003, p. 182), o caos que é a vida real para quem quer fazer uma obra.

Duas leis guiam a obra de arte: a lei da personagem e a lei do autor - uma lei do conteúdo e uma lei da forma... Um autor não pode inventar uma personagem desprovida de qualquer independência em relação ao ato criador do autor, ato esse que a afirma e enforma. (BAKHTIN, 2003, p. 183)

A teoria da alma torna-se uma solução de compromisso entre a abertura que é a visão de si sobre si e o fechamento, que é visão do outro. O estilo não é a forma como tal, mas o que coloca em relação ao que é próprio do herói e à orientação do autor.

\begin{abstract}
A unidade segura do estilo (grande e vigoroso) só é possível onde existe unidade da tensão cognitivo-ética da vida, indiscutibilidade do ante-dado guiado por ela: estaé a primeira condição. A segunda são a indiscutibilidade e a conviç̧ão da posição de distância (em suma, como veremos, a confiança religiosa no fato de que a vida não é solitária, é tensa e se move a partir de si mesma não em um vazio axiológico), o lugar sólido e inquestionável da arte no conjunto da cultura. (BAKHTIN, 2003, p. 186)
\end{abstract}

Seria fácil se surpreender com esse apelo de Bakhtin à religião. Também poderíamos nos questionar sobre o que faz com que aqueles que não são religiosos, no sentido estrito do termo, não mergulhem no desespero ou no tédio. Talvez pelo hábito, estetismo ou porque não sabemos de que são feitas as forças que nos fazem manter a cabeça fora da água?

\title{
b) Heterogeneidade e dialogismo
}

É necessário salientar que a oposição entre textos monológicos e textos dialógicos não invalida o fato da contradição das posições do autor e do herói: a exotopia do autor é a condição mesma que viabiliza a possibilidade de dar a palavra a vários heróis ou a várias vozes.

Lembro muito rapidamente que Bakhtin coloca Dostoiévski na perspectiva histórica da cultura popular caracterizada pela diversidade e transgressão em face da cultura erudita, monológica, ilustrada pela primeira vez pela teologia e por uma forma universalista de Aufklärung. Bakhtin observa, certamente, que há humor em Cândido, mas nenhuma heterogeneidade: o herói como as outras personagens são manipulados de acordo com a vontade do autor. Bakhtin observa que Dostoiévski, ao contrário, suportava mal a expressão terminada, acabada na forma de aforismos. São os heróis "monológicos" que nele se exprimem assim. Se o pensamento é dialógico e ele o é, então o pensamento na forma de aforismos que introduz o fechamento é necessariamente uma forma de pensamento inadequado (BAKHTIN, 1997, p. 113).

Essa cultura popular (da qual Rabelais faz uma recuperação erudita) é baseada na violência, na transgressão, na inversão de valores, nos jogos, nas festas, nas múltiplas vozes como fenômenos centrais do pensamento popular. Essas características são, certamente, na maioria das vezes dominadas por poderes monológicos. Mas a ironia, a festa, a multiplicidade, o escárnio, a farra de gastos, ou, usando outro vocabulário, a "parte maldita" não são fenômenos menores em relação à voz solene que supostamente diz a verdade. É a partir desse pensamento plural, carnavalesco e popular, como ele aparece nas festas, que todos os valores são invertidos, como nas festas e mistérios da Idade Média que colocam os ricos, os bispos e monges no inferno. Certamente, Bakhtin considerava essa voz como a do povo. Mas o que poderia representar esse elogio das múltiplas vozes em 1929 ?

François | Trad. Cunha Dialogismo das "vozes" e heterogeneidade constitutiva do sentido. o "literário" 
Ainda assim, para Bakhtin, é nos romances de Dostoiévski que toma forma por excelência o dialogismo. As obras de Dostoiévski e os textos de Bakhtin sobre essas vozes são bem conhecidos. Mas gostaríamos de lembrar que não se trata de análise formal do romance, muito menos de análise linguística da circulação dialógica, mas de representação estética de conflitos morais, conflitos que se apresentam em figuras concretas e não podem ser reduzidos à ilustração de princípios abstratos.

\section{DOSTOIÉVSKI E O DIALOGISMO: DOIS EXEMPLOS}

\subsection{A infelicidade da consciência em Memórias do Subsolo}

Um primeiro aspecto extremo do dialogismo aparece nas Memórias do Subsolo, que ilustram a infelicidade de alguém que é somente diálogo consigo mesmo, que pretende ser inteligência pura, olhar puro, sujeito puro. Em um primeiro momento, parece doença discursiva da autoanálise perpétua.

\footnotetext{
Não consegui chegar a nada, nem mesmo tornar-me mau: nem bom nem canalha nem honrado nem herói nem inseto. Agora vou vivendo os meus dias em meu canto, incitando-me a mim mesmo com o consolo raivoso -que para nada serve -- de que um homem inteligente não pode, a sério, tornar-se algo, e de que somente os imbecis conseguem. (DOSTOIÉVSKI, 2000, p. 17)
}

E esse primeiro ridículo (essa deploração dura das páginas) é acompanhado por um segundo, quando ele conta suas tentativas que sempre fracassam para esbarrar no ombro do oficial que o empurrou, participar de um jantar de despedida, para o qual ele não foi convidado pelos ex-colegas que ele despreza, ou quando fracassa na tentativa tímida de amor com uma jovem prostituta, porque ele não sabe como lhe falar quando, a seu pedido, ela vem à casa dele:

Mas assim que eu percebi este primeiro surto de orgulho ferido, eu
comecei a tremer de raiva e eu imediatamente explodi:

-- Diga-me, por favor, para que veio a minha casa? -- comecei perdendo o fôlego e até mesmo sem atentar para a ordem lógica das minhas palavras. Eu queria dizer tudo de uma vez, numa rajada; nem me preocupou sequer saber por onde começar. -- Por que você veio? Responda! Responda! exclamava, quase perdendo a consciência de mim mesmo. -- Vou dizer-lhe, mãezinha, para que veio aqui. Veio porque eu disse então a você palavras piedosas. Pois bem, você ficou enternecida com elas, e agora quis ouvir de novo "palavras piedosas". Pois saiba, saiba de uma vez, que eu então estava rindo de você. E agora também rio. Por que está tremendo? (DOSTOIÉVSKI, 2000, p. 137)

Cada vez Dostoiévski justapõe sempre nas palavras do herói seus projetos e sua contradição com seus atos efetivos ou com a realidade que ele encontra. Poderíamos falar aqui de um dialogismo miserável. Deixo em aberto a questão de saber se cada um não encontra um pouco de si mesmo nesse diálogo-monólogo sinistro.

\subsection{O Grande Inquisidor e Jesus em Os Irmãos Karamazov}

Em compensação, o aspecto fascinante de Os Irmãos Karamazov é a presença de contradições e a impossibilidade de se perceber como uma personalidade mais feliz ou mais determinada poderia superá-las. Assim, no diálogo dentro do diálogo que é a fábula do Grande Inquisidor relatada por Ivan a seu irmão Aliócha, onde o "Grande Inquisidor” anuncia ao Cristo de retorno à terra que ele o fará executar e, em seguida, o deixará fugir. Mas o que é mais impressionante é que primeiramente o Grande Inquisidor fala enquanto Cristo se cala e o que diz o Grande Inquisidor, sem ser refutado, é que Cristo está enganado. Ele quis que os homens o amassem livremente, sem convencê-los por milagres. E ainda assim os homens não apenas querem acreditar, mas, além disso, 
todos juntos. Pois essa necessidade de convergência na sujeição é que constitui o tormento principal de cada homem individualmente e de toda a humanidade desde o início dos tempos. Por se sujeitarem todos juntos eles se exterminaram uns aos outros a golpes de espada. [...] Tu o conhecias, não podias deixar de conhecer esse segredo fundamental da natureza humana [...]. (DOSTOIÉVSKI, 2008, p. 352)

E ao mesmo tempo (peço desculpas, estou resumindo), Cristo não quis conseguir pelo "pão" os milagres materiais: "Desejaste o amor livre do homem para que ele te seguisse livremente, seduzido e cativado por ti. Tu mesmo lançaste as bases da destruição de teu próprio reino, e não culpes mais ninguém por isso" (DOSTOIÉVSKI, 2008, p. 353).

Aqueles que têm o romance em mente vão se lembrar sem dúvida do final:

Quando o inquisidor calou-se, ficou algum tempo aguardando que o prisioneiro lhe respondesse. Para ele era pesado o silêncio do outro. Via que o prisioneiro o escutara o tempo todo, com ar convicto e sereno, fitando-o nos olhos e, pelo visto, sem vontade de fazer nenhuma objeção. O velho queria que o outro lhe dissesse alguma coisa ainda que fosse amarga, terrível. Mas de repente, ele se aproxima do velho em silêncio e calmamente lhe beija a exangue boca de noventa anos. Eis toda a resposta. O velho estremece. Algo estremece na comissura dos seus lábios; ele vai à porta, abre-a e diz ao outro: 'Vai e não voltes mais... Não voltes em hipótese nenhuma... nunca, nunca!' E o deixa sair para as 'ruas largas e escuras da urbe'. O prisioneiro vai embora. (DOSTOIÉVSKI, 2008, p. 354)

Reproduzi esse famoso trecho, em primeiro lugar, porque fornece um exemplo de diálogo sem excesso possível. Mas também porque o conflito moral ou religioso, como se queira, faz sentido no detalhe da função estética da dramatização.

Daí a crítica da falsa psicologia científica e, em especial, do Poder Judiciário. No caso do julgamento de Dmitri,

[...] o juiz de instrução, os juízes e o promotor, o defensor e a perícia são igualmente incapazes de penetrar sequer no núcleo inacabado e irresoluto da personalidade de Dmitri, que, em essência, passa toda a sua vida no limiar de grandes decisões e crises internas. No lugar desse núcleo vivo, que germina com a nova vida, eles colocam uma espécie de definição preconcebida, predeterminada "natural" e normalmente em todos os seus termos e nos atos pelas "leis psicológicas". [...] Eis porque Dostoiévski não se considerava psicólogo em nenhum sentido. (BAKHTIN, 1997, p. 62)

É por isso que Dostoiévski não se considerava, em nenhum caso, como um psicólogo. Bakhtin afirma: "É necessário salientar que, no universo de Dostoiévski, até o assentimento conserva o seu caráter dialógico, ou seja, nunca leva à fusão das vozes e verdades numa verdade impessoal, una como ocorre no universo monológico" (Bakhtin, 1997, p. 95). (Vemos aqui que o "mundo do monólogo" significa não só uma característica da língua, mas a violência do discurso de juízes e “eruditos").

Que o romance de Dostoiévski seja assim é notório. Esse dialogismo é a única verdade do pensamento de Dostoiévski? Podemos levantar a questão.

Assim, em Memórias do subsolo, também aparece por um lado a contingência histórica do herói:

[...] tanto o autor como o texto destas memórias são, naturalmente, imaginários. Todavia, pessoas como o seu autor não só podem, mas devem até existir em nossa sociedade, desde que consideramos as circunstâncias em que, de um modo geral, ela se formou. O que pretendi foi apresentar ao público, de modo mais evidente que o habitual, um dos caracteres de um tempo ainda recente. Trata-se de um dos representantes da geração que vive os seus dias derradeiros. (DOSTOIÉVSKI, 2000, p. 14).

Confesso que eu não sei ao certo "para onde ir". Será que essas palavras traduzem a verdadeira relação do autor com o "real”? Será que ele realmente pensa que tal personagem pertence ao passado? Ou há escárnio? Ou o espaço de suspensão do romance é que permite que essas questões permaneçam sem resposta? 
Mas então essa contingência é correlativa de um certo domínio do narrador que encontramos nos Irmãos Karamazov. Parece-me finalmente que isso não é uma objeção, mas sim uma ilustração da contradição da própria obra literária que mostra a tensão moral, existencial, aberta ao futuro no universo fechado da obra, em que a ideia não é separada da contingência do devir concreto, contingência atualizada pela exotopia do autor.

Bakhtin, por vezes, "dá a entender que" o dialogismo se manifestasse apenas da obra de Dostoiévski. Então, depois do que ele disse da crítica à psicologia objetiva do mundo judiciário, Bakhtin acrescenta que "a ênfase principal de toda a obra de Dostoiévski, quer no aspecto da forma, quer no aspecto do conteúdo, é uma luta contra a coisificação do homem, das relações humanas e de todos os valores humanos no capitalismo" (BAKHTIN, 1997, p. 62), acrescentando que ele "vez por outra 'confundia os endereços sociais', nas palavras de V. Iermilov, acusando, por exemplo, todos os representantes da corrente democrática revolucionária e do socialismo ocidental, considerado por ele um produto do espírito capitalista” (BAKHTIN, 1997, p. 63). Mas sua defesa da posição literária de Dostoiévski vai além, parece-me, da literatura:

[...] para o autor o herói não é um "ele" nem um "eu", mas um "tu" plenivalente, isto é, o plenivalente 'eu' de um outro (um 'tu és'). O herói é o sujeito de um tratamento dialógico profundamente sério, presente, não retoricamente simulado ou literariamente convencional. E esse diálogo - o 'grande diálogo’ do romance na sua totalidade como um todo - realiza-se não no passado, mas neste momento, ou seja, no presente do processo artístico. (BAKHTIN, 1997, p. 63)

E ele prossegue em nota de rodapé: “o sentido não 'vive’ no tempo em que há o 'ontem', o 'hoje’ e o 'amanhã', isto é, no tempo em que 'viveram' os heróis e transcorre a vida biográfica do autor” (BAKHTIN, 1997, p. 63, nota 2).

O que pode ser visto mais claramente no capítulo 3 do livro de Dostoiévski (“A ideia em Dostoiévski”). Ao contrário de romances monológicos onde há as ideias do autor ou opiniões externas,

[...] a ideia, como a considerava Dostoiévski-artista, não é uma formação psicológica individual subjetiva com "sede permanente" na cabeça do homem; não, a ideia é interindividual e intersubjetiva, a esfera de sua existência não é a consciência individual, mas a comunicação dialogada entre consciências. A ideia é um acontecimento vivo, que irrompe no ponto de contato dialogado entre duas ou várias consciências. (BAKHTIN, 1997, p. 87)

Bakhtin acrescenta que essas ideias não foram criadas, mas encontradas e que o trabalho de Dostoiévski, sua exotopia, foi reanimálas no corpo (a palavra não está em Bakhtin) falante de seus personagens.

Não poder multiplicar as citações de Dostoiévski e de Bakhtin me deixa particularmente infeliz, porque em um assunto para mim "difícil de pensar" como esse, há um ritmo dos textos que nos faz pensar-sentir, que modifica a repercussão em nós, o que citações de aforismos não podem fazer. O certo é que estamos muito longe do "marxismo comum”, mas também do curso normal da teoria. Bakhtin dá uma forma reflexiva ao que é feito por Dostoiévski: o sentido é um acontecimento, e não uma característica interna dos "enunciados-verdadeiros". Ao mesmo tempo, esse acontecimento não é prisioneiro do momento em que foi enunciado. É isso que nos permite falar de "espaço de suspensão", que ao mesmo tempo é proposto pela obra e depende da nossa capacidade de resposta.

Gostaria aqui de associar alguns textos teóricos de Bakhtin dos anos 1920 e do final de sua vida. Acredito que eles nos permitem, tanto uns como outros, não reduzir o dialogismo ou a intertextualidade a técnicas pedagógicas de decifração ou a traços acidentais de alguns romances. O texto de Bakhtin Para uma filosofia do ato (inédito, escrito provavelmente entre 1920 e 1924) é conciso, está faltando páginas. Abordo o que segue, o estilo conciso tornando nefasto ou medíocre toda tentativa de paráfrase: Bakhtin parte do fato de que o modo de conhecimento teórico não é o mundo da contemplação estética nem é aquele em que vivemos e agimos. Mas, ao mesmo tempo, esses mundos se cruzam: assim a atemporalidade do mundo das verdades só se realiza no instante concreto em que ocorrem. Bakhtin toma o exemplo central da vida e morte de Cristo: 
[...] este mundo, o mundo em que se completou, enquanto fato e sentido, o evento da vida e morte de Cristo é, por princípio, indeterminável seja mediante as categorias teóricas, seja através das categorias do conhecimento histórico, seja por meio de uma intuição estética. No primeiro caso, conhecemos de fato o sentido abstrato, mas perdemos o fato singular do efetivo cumprir-se histórico real do evento; no segundo, há o fato histórico, mas perdemos o sentido; no terceiro, temos tanto a existência do fato quanto o seu sentido como momento de sua individuação, mas perdemos a nossa posição em relação a ele, perdemos nossa participação respondente àquilo a que somos chamados. (BAKHTIN, 2010, p. 64)

Em nenhum caso, temos o "sentido total". E a partir daí, Bakhtin observa que há apenas filosofias de especialidades e não uma filosofia primeira (BAKHTIN, 2010, p. 68). Daí a insatisfação daqueles que "pensam de modo participante”, insatisfação que os leva a voltar-se para o materialismo histórico, apesar de todas as suas deficiências e defeitos, especialmente em termos da sua incapacidade real para relacionar teoria e prática (BAKHTIN, 2010, p. 64). Outros buscam nas tradições religiosas "que absorveram muito da sabedoria real do pensamento participativo medieval e oriental” (BAKHTIN, 2010, p. 69), embora sejam totalmente insatisfatórias "não como simples compilações de visões particulares do pensamento participante através dos séculos", mas como concepções unas, que "cometem o mesmo pecado metodológico do materialismo histórico, o da indiscriminação metodológica do que é dado e do que é posto como tarefa, entre o que é e o que está ainda por ser realizado" (BAKHTIN, 2010, p. 69).

Se nos colocarmos face à ideia não de um Deus do alto, mas de um universo partilhado com Cristo, estamos longe de qualquer possibilidade unificadora. Temos de admitir que estamos em um universo dissociado onde a relação entre a ordem pensada do mundo e o que pode ser obedecer na procura de uma vida satisfatória não têm praticamente relação. E poderíamos provavelmente argumentar que a figura do amor de Cristo, quer sejamos crentes, quer não, nos afasta de qualquer filosofia da totalidade.

Em todo caso, de um ponto de vista mais limitado, é incontestável que o pensamento de Bakhtin nos leva a separar o dialogismo de uma análise dos "fatos da língua" unicamente, para levar em conta a natureza dialógica do homem. Permitam-me aqui uma citação relativamente longa de Bakhtin:

Se por um lado posso aspirar diretamente à autopreservação e, ao defender minha vida a qualquer preço, até mesmo almejar o poder e a submissão dos outros, nunca, porém, posso vivenciar imediatamente em mim aquilo que vem a ser a pessoa de direito, visto que a pessoa de direito não é senão a certeza garantida de meu reconhecimento pelos outros, reconhecimento esse que eu vivencio como uma obrigação deles para comigo (porque uma coisa é defender de fato a própria vida contra um ataque real - até os animais fazem assim - e outra coisa inteiramente distinta é vivenciar seu próprio direito à vida e à segurança e a obrigação de que os outros respeitem esse direito), tão profundamente diversos são o vivencialmente interior do próprio corpo, o reconhecimento do seu valor externo por outras pessoas e meu direito à aceitação amorosa da minha imagem externa: tal reconhecimento me chega de cima como um dom concedido pelos outros, uma felicidade que não pode ser interiormente fundamentada e compreendida. [...] De fato, mal a pessoa começa a vivenciar a si mesma de dentro, depara imediatamente com atos de reconhecimento e de amor de pessoas íntimas, da mãe que partem de fora ao encontro dela: dos lábios da mãe e de pessoas íntimas a criança recebe todas as definições de si mesma. Dos lábios dela, no tom volitivo-emocional do seu amor, a criança ouve e começa a reconhecer o seu nome, a denominação de todos os elementos relacionados ao seu corpo e às vivências e estados interiores; são palavras de pessoas que ama as primeiras palavras sobre ela, as mais autorizadas, que pela primeira vez lhe determinam de fora a personalidade e vão ao encontro da sua própria e obscura auto-sensação interior, dando-lhe forma e nome em que pela primeira vez ela toma consciência de si e se localiza como algo. (BAKHTIN, 2003, p. 45-46)

E logo depois Bakhtin retoma "palavras amorosas e preocupações reais...": "A criança começa a ver-se pela primeira vez como que pelos olhos da mãe e começa a falar de si mesma nos tons volitivo-emocionais dela, como que se acaricia com sua primeira autoenunciação" (BAKHTIN, 2003, p. 45-46). Bakhtin escreve também sobre essa fala e esses cuidados como dando uma "forma plástica" sem limites, "caos agitado" de necessidades e insatisfações. O aspecto surpreendente deste trecho é mostrar o amor do outro como o que me dá o direito de existir. Pode-se notar também que essa ordem simbólica aqui vem da mãe. Nesse sentido, não é "naturalmente" que o humano é humano. No entanto, existem raízes quase naturais nesse tornar-se humano. 
Se partirmos dessa nota de Bakhtin, podemos nos perguntar sobre o modo de ser dos "outros", modo de ser, sobre o qual me parece que nós não sabemos bem como dar uma representação teórica, mesmo se é uma coisa muito banal. Falar de "empatia" é um risco, podendo não explicar nada, porque o que importa não é se identificar com o outro, já que o que há de notável na criança é a sua capacidade de articular seu próprio jogo com a esquisitice dos adultos profundamente diferentes delas. E, por outro lado, falar de "imaginação" ou, em outro estilo, de "fantasmas" também não faz mais do que dar um nome à alteridade familiar. Assim como somos incapazes de coincidir com nós mesmos, "eu" visto de dentro e "eu" visto de fora. Da mesma forma que o conceitual e o imagético não podem convergir, nem o que eu sinto e o meu dizer em relação ao meu sentimento.

Nos últimos textos de Bakhtin (por exemplo, em seu último texto de 1974, Metodologia das ciências humanas), seria possível encontrar a mesma irredutibilidade da multiplicidade de perspectivas, dessa vez, em relação ao conhecimento. Ele lembra as razões de sua oposição ao estruturalismo:

\footnotetext{
No estruturalismo, existe apenas um sujeito - o próprio pesquisador. As coisas se transformam em conceitos (de um grau variado de abstração); o sujeito nunca pode tornar-se conceito (ele mesmo fala e responde). O sentido é personalista; nele há sempre uma pergunta, um apelo e uma antecipação da resposta, nele sempre há dois (como mínimo dialógico). Este personalismo não é um fato psicológico, mas de sentido. Não existe a primeira nem a última palavra, e não há limites para o contexto dialógico (este se estende ao passado sem limites e ao futuro sem limites). (BAKHTIN, 2003, p. 410)
}

Ele acrescenta de modo um pouco enigmático para mim que os sentidos passados são sempre passíveis de mudança em um diálogo futuro: "Não existe nada absolutamente morto: cada sentido terá sua festa de renovação. Questão do grande tempo" (BAKHTIN, 2003, p. 410). O que esclarece talvez o que é dito da atemporalidade relativa da obra.

A visão de mundo de Bruner é certamente menos dramática do que a de Bakhtin e ainda menos do que a de Dostoiévski. No entanto, pode-se dizer que em uma época bem mais "científica", ela lhe dá continuidade. Em primeiro lugar, na medida em que ele observa que a "psicologia popular" (isto é, a psicologia de cada um de nós envolvidos na vida) é uma psicologia narrativa. Na medida em que, primeiramente, a vida não é feita de leis, mas de heterogeneidade entre momentos fortes e fracos, acontecimentos e rotinas, e também em que essa vida envolve tanto a generalidade do "se"13 e a particularidade, a diferença de cada um, finalmente, porque a ficção e a realidade são feitas do mesmo material, cada um de nós (no modelo da personagem do subsolo) passa seu tempo vivendo no contraste de suas lembranças, seus planos e seus modos efetivos de fazer. Parece-me que a reflexão sobre os textos de Vigotski ajuda a estabelecer a relação entre as obras literárias e a vida cotidiana.

Gostaria de acrescentar um último ponto. Pode-se falar de círculo hermenêutico. Mas esse círculo não é um círculo de conhecimento puro. Não podemos esquecer o estado necessariamente obscuro dessa relação com os outros (e aliás com nós mesmos). Primeiramente, em função da anterioridade de uma relação vivida com os outros antes de qualquer explicitação. Em seguida, por causa da natureza "impura" da nossa paixão de compreender ou de ter razão, sendo o páthos de ter razão muito mais violento do que a mais violenta das libidos (lembro, a propósito, que muitas das autoanálises dos sonhos de Freud incidem sobre a força de seu desejo de ter razão). O que pode ser encontrado nas diferenças culturais. No artigo sobre os estudos literários (NOVY MIR, 1970), Bakhtin desenvolve a ideia de que, no ato de compreensão, apreende-se uma cultura estrangeira apenas de fora, da mesma forma que eu como corpo só posso ser apreendido pelo outro:

[...] a cultura do outro só se revela com plenitude e profundidade (mas não em toda a plenitude, porque virão outras culturas que a verão e compreenderão ainda mais) aos olhos de outra cultura. [...] Colocamos para a cultura do outro novas questões que ela mesma não se colocava; nela procuramos respostas a essas questões e a cultura do outro nos responde, revelando-nos seus novos aspectos, novas profundidades do sentido. (BAKHTIN, 2003, p. 366)

\footnotetext{
${ }^{13}$ N.T.: Ver nota 9
} 
Não vivendo na época de Platão, podemos perceber a maneira particular de dialogar de Sócrates, como é preciso estar longe da vida de Cristo para ser capaz de imaginar o que é um homem que não tem uma cultura urbana. Daí a necessidade da "compreensão desconcertante" (BAKHTIN, 2003, p. 366).

Mas o que Bakhtin também nos lembra é que se trata de levar em conta não só a violência sempre no horizonte dos conflitos (especialmente naqueles das gerações), mas também que nunca poderá haver uma verdadeira reunificação do mundo teórico e do mundo da vida. Haverá, o que já é bom, modos de funcionamento da linguagem que nos lembram o que o curso da vida nos permite esquecer ou o que faz com que possamos tentar não identificar a idiossincrasia das nossas modalidades dialógicas e a suposta universalidade da natureza humana que uma abordagem científica permitiria.

4 A TEORIA DAS EMOÇÕES E A DA ARTE EM VIGOTSKI vão, portanto, ser expostas aqui sem colocá-las em relação com o resto do seu pensamento. Lembramos, contudo, que, sobre a relação da linguagem com o extraverbal, Vigotski desenvolveu, nos textos bem conhecidos de Pensamento e linguagem, uma visão bastante original: a linguagem e o pensamento têm diferentes fontes, sua reunião produz efeitos inesperados. Essa visão vai contra duas opiniões predominantes: a que pode ser chamada de "clássica", segundo a qual o pensamento é expresso de alguma maneira do exterior na linguagem, e a que faz da linguagem a única fonte do sentido, o que está, talvez, perdendo fôlego em algumas correntes estruturalistas, lacanianas ou outras. Lembramos aqui também o que é completamente original na observação de Vigotski sobre a diferença entre o que é transmitido na educação escolar e o que é noção adquirida no curso da vida, ainda que os exemplos sejam um pouco simples e que a realidade contraditória dos modos de transmissão seja mais complexa. Contudo, ele mostrou que falar da criança não é procurar uma origem. Assim, a pluralidade dos modos de pensamento é dada corporalmente à criança pela diferença entre o momento pulsional, o da atenção calma e o do sono, da mesma forma que o sonho lhe dá um quase outro mundo e esse sonho vai ser uma oportunidade para encontrar universais como a violação da intimidade, o ato de devorar ou o perigo que há em se aventurar no desconhecido. Um pouco como, por razões que não são totalmente claras para mim, a maior parte das crianças pequenas encontra por elas mesmas o tema dos animais participando de uma vida comum com a humanidade.

Dito isto, eu não vou desenvolver longamente a apresentação do texto de Vigotski sobre a teoria das emoções (Teoria das emoções, elaborado em 1931, deixado inacabado, anterior portanto a Pensamento e linguagem 1929-1934). Em primeiro lugar, é muito bem resumido pelo artigo de Rochex. Para mim, ele também apresenta a mesma vantagem que o da teoria da arte de não ser ainda conhecido. Mas parece-me que o leitor se confronta com um muro: Vygotzki, ao proclamar sua fidelidade a Espinosa, continua trazendo à tona a polêmica contra a teoria periférica das emoções de James-Lange, que não dá conta da diversidade da vida afetiva dos que têm o mesmo distúrbio fisiológico, o que é óbvio. Ele polemiza da mesma forma contra Descartes e contra a glândula pineal como lugar problemático da união da alma e do corpo, o que é certamente correto. A isso, poderíamos acrescentar que o recurso a Espinosa e ao paralelismo dos dois atributos não é uma reflexão fácil para nós, especialmente porque, de acordo com Espinosa, os atributos são em número infinito. É evidente que a ideia de Espinosa de que nossas paixões fazem nossa força muda a perspectiva, mas, no texto de Vigotski, ela é apenas esboçada. Do mesmo modo, é feita uma alusão à ideia aristotélica da alma como forma do corpo, que poderia ser objeto de reflexão, mas não é desenvolvido.

Vigotski observa também a especificidade da admiração como paixão sem contrário e primeira paixão para Descartes. Esta é uma ideia-experiência, e não o desenvolvimento de uma teoria: o objetivo não é, provavelmente, constituir belos sistemas, mas organizar o pensamento em torno de polos resistentes. Aqui, o primado da admiração poderia orientar para um pensamento que se oporia ao darwinismo, na medida em que esse último só quer considerar o que é condicionado pela visão utilitarista ou não para o indivíduo ou para a espécie; ou ao freudismo na medida em que a criança de Freud é definida primeiramente como pulsional em um sentido mais restrito do que a capacidade de admirar e se surpreender. No entanto, o que Vigotski procura é uma teoria que não separa "inferior" e "superior", como quando ele menciona que a vida cultural está presente, de alguma forma, em todas as nossas emoções. Por exemplo:

[...] entretanto, ao que parece, todas as emoções humanas devem ser colocadas na categoria de emoções leves, porque se colocarmos de lado os idiotas, o indivíduo muito limitado está sempre em relação com algum ideal mais ou menos vago, com alguma consciência mais ou menos perceptível. Os sentimentos mais baixos

François trad. Cunha | Dialogismo das "vozes" e heterogeneidade constitutiva do sentido. o "literário". 
sobrevieram sob a influência de tradições, crenças ou preconceitos religiosos. Eles não são de uma forma que se possa considerá-los como reações instintivas a estímulos que não dependem de um sistema ideologicamente estabelecido. (VIGOTSKI, 1998, p. 348)

Ou, um pouco mais adiante:

Não podemos admitir que apenas a percepção de uma silhueta feminina, de onde poderia nascer um amor como o de Dante por Beatriz, se não se pressupõe todo um conjunto de ideias teológicas, políticas, estéticas, científicas que constituíam a brilhante consciência do genial Alighieri. (VIGOTSKI, 1998, p. 348)

Mas, Vigotski procura, principalmente, uma entrada neurológica (usando assim Cannon e o papel do sistema nervoso autônomo) para explicar a desordem geral, deixando explicações de outros tipos para a natureza específica das emoções. De qualquer forma, esse texto é um esboço inédito. Há outros textos entre aqueles que estão à nossa disposição, principalmente um texto muito mais curto, "As emoções e seu desenvolvimento nas crianças" (1932), no qual ele cita muitos autores. Um parêntese: vemos se anunciar o peso de chumbo do pensamento oficial. Mas o pensamento de Vigotski como o dos outros autores é irrigado por correntes bastante diversas. É claro que os autores são frequentemente catalogados como “idealistas" e "materialistas", mas Vigotski interessa-se sobretudo pelas diferenças entre eles. Ele apela para Bühler, na medida em que este constrói um esquema das emoções e mostra que elas não desempenham sempre o mesmo papel em relação a outras funções psíquicas. Assim, ele distingue Endlust, o prazer final da saciedade de fome ou sede, e, em seguida, o prazer funcional (Funktionslust), que é aquele que acompanha uma atividade em si, o prazer mesmo de comer (gula). Finalmente o prazer antecipador Vorlust, que irá caracterizar a tendência humana de viver no irreal do representado. Pode-se notar aqui a ausência da lembrança do prazer perdido, tão importante em Freud. Acima de tudo, vamos encontrar em Pensamento e linguagem uma diferença homóloga entre o discurso que acompanha a ação, o que a anuncia e aquele que a comenta. Pouco importa aqui que se possa fazer um catálogo desses modos de ser. O que importa é a existência de diferenças.

No pequeno texto de Vigotski, apresentado em apêndice ao livro de Brossard (2004), é feita referência ao exemplo relatado por Lévy-Bruhl, que Vigotski cita na história do desenvolvimento das funções mentais superiores: o chefe de uma tribo da África do Sul, a quem o missionário aconselha enviar seu filho à escola, responde: "vou ver o que meus sonhos ditarão para mim". Esse exemplo é para mim símbolo, e não alegoria, no sentido de que não é uma verdade geral já posta, mas dá um sentido que não pode ser substituído por um discurso abstrato. O sonho é natural, mas se questionar, remeter ao passado, ao futuro ou achá-lo obscuro é cultural. Mas uma cultura que não é pura retomada do discurso indeterminado ${ }^{14}$ no indivíduo, mas retomada em uma dada circunstância, o que faz com que não se possa provavelmente distinguir de forma clara o que é pensamento do "eu" e o que é pensamento indeterminado ${ }^{15} \mathrm{em}$ cada um de nós. Mas parece-me que o estudo dessas mudanças de lugar é mais importante do que um estudo da "natureza" dos objetos (o que é a linguagem? A afetividade? A inteligência? Ou as origens?).

Parece-me que a entrada menos ruim que nos é oferecida aqui é aquela que se questiona sobre o renascimento com o desenvolvimento de cada criança do objeto cultural e de sua tonalidade afetiva. Isso pode ser ilustrado por dois nomes. Em primeiro lugar, é provavelmente em Wallon que aparece mais claramente a ligação ao outro como biologicamente programada:

Não é apenas o primeiro comportamento psíquico da criança que é do tipo afetivo, mas também o da idiotice em seu nível mais baixo. A agitação correspondente é feita então apenas de gritos, nos quais se sucedem as entonações da cólera, do triunfo, do sofrimento e de atitudes ou de gestos cuja significação emocional não deixam nenhuma dúvida. Esses efeitos muitas vezes são produzidos com a simples presença de outrem, mostrando assim a que camada primitiva e profunda da sensibilidade pertencem as reações que podem ser chamadas de presença, porque elas parecem ser reflexo da personagem que cada um carrega em si em relação a todo ser encontrado. (WALLON, 1941, p. 118)

\footnotetext{
${ }^{14}$ N.T.: Discurso do “on”. Ver nota 9.

${ }^{15}$ N.T.: Pensamento do “on”. Ver nota 9.
} 
Duas observações aqui se fazem necessárias: um elemento da teoria, como no caso da admiração em Descartes, poderia ser chamado de elemento choque, experiência e o mistério envolto nesse uso de "parecem". O que caracteriza o estilo de Wallon é que ele insiste no que há de difícil na descrição, o que explica sem dúvida que ele tenha tido menos sucesso que os autores, cujo pensamento mais unívoco é mais facilmente repetível.

\begin{abstract}
O grito do recém-nascido chegando ao mundo, grito de desespero segundo Lucrécio, em face da vida que se abre para ele, o grito de angústia segundo Freud, no momento em que ele se desliga do corpo da mãe, não significa outra coisa para o fisiologista senão um espasmo da glote, que é acompanhado pelos primeiros reflexos respiratórios. Mas a sua redução a um simples fato muscular é apenas uma abstração. Ele pertence a um complexo vital. Ao espasmo está ligado o grito, mas também um conjunto de condições e impressões simultâneas que se exprimem no espasmo como no grito. Nesse estágio elementar, não pode haver distinção entre o signo e a causa. (WALLON, 1941, p. 120)
\end{abstract}

A descrição não é o estágio mais simples do pensamento antes da explicação. Em todo caso, que o grito se torne signo continua a ser um exemplo central do dialogismo, levando a efeitos no próprio organismo daquele que grita. Aqui temos um exemplo simples da epigênese não milagrosa. Acrescenta-se que esse circuito permite variações, o que se manifesta na forma como a criança reutiliza o grito em questão de maneira eventualmente lúdica ou abusiva. Ao mesmo tempo, seu próprio grito age nele. Por exemplo:

As emoções, que são a exteriorização da afetividade, iniciam assim mudanças que tendem a reduzi-las. Nelas são baseados treinamentos gregários que são uma forma primitiva de comunhão e comunidade. As relações que elas tornam possíveis aperfeiçoam os seus meios de expressão, fazendo delas instrumentos de sociabilidade cada vez mais especializados. (WALLON, 1941, p. 126)

Assim, a mímica separa-se da emoção.

Há outro eixo em Winnicott com a ideia do objeto transicional, que não é nem interno nem externo. Parece-me, portanto, ser um acréscimo a Freud, mas ele subverte, para mim, o freudismo, inteiramente construído sobre o interno insuportável da pulsão e os mecanismos de defesa, enquanto, em Winnicott, o objeto cultural é partilhado, mas sempre de maneiras diferentes pela criança e pelo cuidador.

O psiquismo não é o exterior nem o interior, mas existe apenas pelo objeto cultural intermediário, que é de tal forma que o que o outro fez não teríamos podido fazer. Trata-se aqui de introduzir o papel dos objetos ou das cerimônias, por exemplo, rituais de reconciliação em macacos. Mas aqui vamos do adulto à criança e ao macaco ao invés de tentar explicar o complexo pelo simples. Conquanto, o paralelo com o objeto transicional concerne o conjunto da cultura, pois toda obra recebida socialmente apresenta sempre a singularidade de que o outro fez algo que não poderíamos ter feito. Por um lado, podemos sempre considerar "loucos" os textos que nos afetam. Com o problema antigo do mistério da "inspiração" e dos poetas "loucos", afinal o narcisismo de Chateaubriand ou de De Gaulle é "louco". Mas não saímos da loucura quando algo como o objeto transicional é possível, embora não seja sempre fácil saber como ele age em nós? Em todo caso, é uma teoria desse modo de ação do objeto cultural que nos propõe Vygotzki. 


\section{O LIVRO PSICOLOGIA DA ARTE E O MODO DE AÇÃO DA OBRA DE ARTE}

Vigotski parte desta constatação de que existem fábulas "elementares", como as de Esopo, que se resumem ao que elas dizem, que são apenas a ilustração de uma generalidade: "Cuidado com os bajuladores". Há outras fábulas, que ele chama poéticas. Ele tomou o exemplo de Shklovsky.

Mas, obviamente, isso se aplica igualmente a La Fontaine, no qual há, por exemplo, o sentido da verdade prosaica da fábula: o elogio da formiga e o sentido dado pela forma viva do discurso que faz o elogio da leveza da cigarra. Ou ainda a violência do lobo que é "em tese" condenada, mas manifestada na sua brutalidade pelo ritmo da frase. Também poderíamos utilizar a prática da dupla verdade no modo como Perrault, sistematicamente, justapõe duas “morais” contraditórias.

Vigotski segue a tradição dos "formalistas" para quem a fábula é a matéria e o tema, o conjunto do seu devir no discurso, na "forma": a forma é então o conjunto do dizer, e não a forma fônica. A ideia defendida por Vigotski é que o que faz a obra de arte é o conflito, a contradição, a tensão entre o conteúdo e a forma (não, como diz a doxa, o acordo entre os dois). Aqui o dialogismo não é a relação entre duas falas, mas a existência de uma tensão entre duas maneiras de significar.

Vou abordar de forma relativamente longa o exemplo do conto de Ivan Búnin Leve alento (1916). Relato aqui o tema ou o conteúdo: uma jovem estudante seduz um homem. Ele mata-a em uma plataforma de trem. Aqui, como na fábula, há o que poderia aparecer em um resumo. Mas essa história "faz sentido” por sua tradução improvável aos olhos da diretora da escola. Mais especificamente por tudo o que na narrativa não segue a ordem "objetiva” da fábula, da história.

O que o gráfico elaborado por Vigotski destaca é a multiplicidade de perspectivas indicadas pelo desenrolar da narrativa, o que, num certo sentido, não passa de um "fait divers"16. O conto tem cinco páginas compactas. Vou lembrar rapidamente (com a inevitável imperfeição que isso representa, em especial, porque perde-se assim o movimento da narrativa), seguindo Vigotski, a diversidade dos movimentos do texto.

1) No cemitério. "No cemitério, sobre um aterro de barro fresco, uma cruz de carvalho nova, forte, pesada, lisa, daquelas que dá até gosto olhar.

2) É abril, mas os dias estão cinza. Os monumentos do cemitério, amplo, verdadeiro cemitério de concelho, ainda se deixam ver de longe por entre as árvores peladas, e um vento frio assobia sem parar numa coroa de porcelana ao pé da cruz.

Na própria cruz embutiram um medalhão de bronze bastante grande, e no medalhão uma foto de uma ginasiana elegante e encantadora, de olhos radiantes, impressionantemente vivos. É Ólia Mieschérskaia" (VIGOTSKY, 1999, p. 201).

3) Seu retrato "objetivo" e "avaliativo": moça bonita "rica e feliz", "aluna inteligente, mas levada, e se descuidava muito dos sermões que lhe pregava a preceptora" ${ }^{\text {"17 }}$. Aos catorze anos, tornou-se uma garota de "cintura fina", "pernas bem feitas, já se delineavam os seios e todas as formas cujo encanto a palavra humana jamais havia expressado (VIGOTSKY, 1999, p. 201). Parece impressionante notar aqui como o romancista é aquele que diz do seu modo o que ele apresenta ao mesmo tempo como verdade geral, marca do que Bakhtin chamaria de sua "exotopia", ou melhor, a forma particular dessa exotopia.

Aos quinze anos, ao contrário daqueles que se importam com sua aparência, "ela nada temia nem as manchas de tinta nos dedos, nem o rosto enrubescido, nem os cabelos despenteados, nem os joelhos à mostra nas quedas ao correr" (VIGOTSKY, 1999, p. 201-202). O autor descreve então o que fazia a sua singularidade: "o que tanto a distinguira de todo o ginásio nos últimos dois anos: a graça, a elegância, a esperteza, o brilho límpido porém

\footnotetext{
${ }^{16}$ N.T.: "Fait divers" é um tipo de notícia que apresenta casos inexplicáveis e excepcionais. Geralmente são acontecimentos trágicos, tais como crimes e acidentes, delitos descritos em poucas linhas.

${ }^{17}$ N.T. François explica que na edição francesa do conto, tem com uma nota do tradutor dizendo se tratar da diretora do colégio.
} 
sagaz dos olhos" (VIGOTSKY, 1999, p. 202). Aqui, o papel da coordenação é dar quase a ver, superar (o que caracteriza justamente a "literatura") a oposição do genérico e do particular.

Mas também se atribuía a ela a frivolidade, a necessidade de ter admiradores; rumores diziam "que o ginasiano Chênchin estava loucamente apaixonado por ela, de que ela também parecia amá-lo, mas o tratava de modo tão inconstante que ele tentara suicídio" (VIGOTSKY, 1999, p. 202).

4) Após esse pano de fundo: "No seu último inverno, Ólia Mieschérskaia desatinara de alegria, como se dizia no ginásio". Ela é convocada pela Diretora que critica seu penteado, sua aparência: "Infelizmente não é a primeira vez que sou forçada a chama-la aqui para lhe falar do seu comportamento"

Nesse ponto sem perder a simplicidade e a calma, Mieschérskaia de repente a interrompeu polidamente: - Desculpe-me, madame, a senhora está equivocada: eu sou uma mulher. E o culpado por isso - sabe quem é? Um amigo e vizinho do meu pai, e vosso irmão, Alieksiêis Mikháilovitch Maliútin. Aconteceu no verão passado, no campo..." (VIGOTSKY, 1999, p. 202-203).

5) (Não há ruptura no texto): "E um mês depois dessa conversa, um oficial cossaco, feio e de aspecto plebeu, sem absolutamente nada em comum com o círculo ao qual pertencia Ólia Mieschérskaia, fuzilou-a na plataforma de uma estação ferroviária, em meio a uma grande multidão que acabava de chegar de trem” (VIGOTSKY, 1999, p. 203).

6) "A confissão inverossímil de Ólia Mieschérskaia, que deixou desconcertada a diretora, foi inteiramente confirmada: o oficial declarou ao juiz de instrução que Mieschérskaia o seduzira, mantivera relações com ele, jurara que se tornaria sua mulher, mas na estação ferroviária, no dia do assassinato [...] disse de repente que todas aquelas conversas sobre casamento não passavam de zombaria com ele e lhe deu para ler as páginas do diário em que ela falava de Maliútin" (VIGOTSKY, 1999, p. 203-204). Foi depois da leitura desse trecho que o oficial tinha matado Ólia.

7) No diário, pode-se ler no dia 10 de julho o relato da vinda de Alieksiêis Mikháilovitch à casa de campo, onde ela estava sozinha: "ele permaneceu porque estava chovendo e queria que secasse até o entardecer. Lamentou muito não ter encontrado papai, esteve muito animado e se comportou como um cavalheiro comigo, brincou muito, dizendo há muito tempo estava apaixonado por mim" (VIGOTSKY, 1999, p. 204).

8) O diário passa então para a descrição de seu interlocutor: "Ele está com cinquenta e seis anos, mas ainda é muito bonito e anda sempre bem vestido - só não gostei de ele ter vindo de capa - cheira a colônia inglesa, tem os olhos bem jovens e a barba toda prateada e elegantemente dividida em duas longas partes" (VIGOTSKY, 1999, p. 205).

9) Ela retorna então ao que aconteceu: não se sentindo muito bem, ela deitou-se em um sofá enquanto eles tomavam chá, "depois sentou-se ao meu lado, passou outra vez a dizer galanteios, a examinar e beijar minha mão. Cobri o rosto com um lenço de seda, e ele me beijou várias vezes na boca por cima do lenço... Não entendo como aquilo pode acontecer, fiquei louca, nunca pensei que eu fosse assim. Agora só há uma saída... Sinto tamanho nojo dele que não posso suportar isso!...”

10) "Nesses dias de abril a cidade anda limpa, seca, as pedras ficaram brancas, e é fácil e agradável andar em cima delas" (VIGOTSKY, 1999, p. 205). O narrador descreve "uma mulher baixinha, de luto", que se dirige todo domingo à cruz de carvalho e permanece uma ou duas horas.

11) "Como ligar esse montículo de barro a essa cruz de carvalho àquela ginasiana de dezesseis anos, que há apenas três meses era tão cheia de vida, encanto e alegria? [...] E como compatibilizar com aquele olhar puro o horrendo que agora está associado ao nome de Ólia Mieschérskaia?”

12) "Mas do fundo da alma a mulher baixinha é feliz, como todas pessoas apaixonadas ou entregues a algum sonho apaixonado” (VIGOTSKY, 1999, p. 205-206)”. 
13) O narrador retorna então à vida da mulher (a Diretora da escola de Ólia), que viveu primeiramente para o seu irmão, militar, e após a morte dele, "ela se convenceu de que [...] ela era uma trabalhadora de ideias" (VIGOTSKY, 1999, p. 206)”. Finalmente, após a morte de Olga, ela apegou-se às lembranças dessa última.

14) O que faz lembrar uma conversa entre Ólia e sua amiga de coração, a grande e gorda Subótina. Olga contoulhe ter lido em um dos livros do seu pai sobre a beleza que deve ter uma mulher: "os olhos negros, fervendo como breu! - os cílios, negros como a noite, o corado de tom suave, talhe fino, braços mais longos que de costume! -, pé pequeno, seios suficientemente graúdos, panturrilha corretamente arredondada, joelhos cor do interior de uma concha, os ombros porém altos - aprendi muita coisa quase de cor, tão importante é tudo isso! - mas sabes o principal? O leve alento! E olha que eu o tenho, Escuta só como eu suspiro -, não é verdade que eu o tenho?" (VIGOTSKY, 1999, p. 206).

15) E o narrador conclui: "Agora esse leve alento volta a espalhar-se pelo mundo, por esse céu nublado, por esse vento frio de primavera” (VIGOTSKY, 1999, p. 206).

Não retomarei todas as análises de Vigotski: elas se referem essencialmente à contradição entre a unidade da notícia e de sua cronologia e à diversidade de perspectivas, particularmente entre as palavras da heroína e a percepção de quem vê do exterior. Mas, principalmente, Vigotski imagina o que seria o enredo da notícia que levou ao tiro de revólver. Aqui, ao contrário, é a diversidade cronológica de perspectivas, o fato de começar e terminar no cemitério, o título e o fim em torno da "respiração leve". O texto acentua constantemente o que pode ter de medíocre a percepção do mundo da heroína.

E, simultaneamente, emerge o que o seu modo de ser tem de frágil, de leve, de charme evanescente. Em particular, vê-se aqui como a exotopia do autor, nas palavras de Bakhtin, é a condição que permite que apareça a diversidade de perspectivas. Ou melhor, como o centro dessa exotopia não é tanto o conhecimento do autor quanto a tensão entre a forma do texto e seu tema.

O que esse texto nos dá é algo que pode ser definido por séries de negativas duplas: primeiro, é um modo de ser que, como tal, não é nem irreal, nem real, mas está presente; isso não faz parte nem do conhecimento nem do sentimento, mas do modo de repercussão, modo de repercussão que tem ecos diferentes em cada um e é, apesar disso, um objeto comum, que tem características essenciais, mas é antes de tudo movimento. É a diversidade dos modos de ser que caracteriza o objeto cultural, especialmente a multiplicidade rítmica da imagem corpo-alma da jovem por meio da multiplicidade de vozes, embora essas vozes não estejam no mesmo plano, a voz dominante sendo a da personagem anônima que "quase vê" (como podemos ver numa narrativa) da ou de uma moça, uma forma de essência concreta (que será tão difícil de perceber no cinema onde o rosto particular do ator ou da atriz tem um peso maior no concreto-genérico do Cristo, de Lolita ou de qualquer herói).

O dialogismo aqui é a irredutibilidade de perspectivas mais que seu conflito. Em certo sentido, o autor é o mestre do que ele faz, mas em outro sentido ele deixa diferentes verdades dominarem nossa leitura. O que se imporá especialmente a nós: a sedução da jovem, a morte, sua leveza, o olhar dos outros ou o movimento entre esses pontos de vista? Ou ainda os detalhes do retrato do que deve ser no livro a verdadeira sedutora?

Não se trata de "contradição" no sentido lógico, mas de tensão entre a fábula e o estilo (e o que o estilo abre como perspectivas). Mas, evidentemente, a fórmula de Vigotski permanece geral. E é da especificidade desse estilo que é necessário dar conta...

Voltando rapidamente ao último exemplo que ele cita, o de Hamlet, Vigotski ridiculariza todos os que explicam o drama pelo caráter hesitante do herói, o que faz esquecer a decisão dele, por exemplo, no assassinato de Polônio ou do rei. Sobretudo, uma tal pesquisa psicológica como a que compararia os caracteres de Édipo e Hamlet esquece que Hamlet tanto quanto Édipo não é um ser real. Pode-se opor a essa "psicologia" uma consideração muito mais inconsistente: se Hamlet estivesse decidido, não haveria peça. O que faz que ela exista como uma forma estética é a heterogeneidade de escritas, os tipos de cenas. Não é "psicologicamente" necessário que um indivíduo seja portador de uma tal heterogeneidade. Hamlet é o suporte de discursos múltiplos, quer seja a conversa com Ofélia, quer seja a conversa com coveiros, quer sejam as reviravoltas da cena do duelo com Laertes e da morte do rei. Da mesma

Fórum linguistic., Florianópolis, v. 13,n.2, p.1260-1294, abr./jun.2016 
forma que não é a "loucura" do herói que justifica a preciosidade de figuras de discurso. Nas palavras de Bakhtin e Kundera, a peça encena o polilogismo interno do herói, como a relação de Shakespeare com o seu herói. Para retomar um outro termo de Bakhtin, mais fortemente sem dúvida do que um romance, uma peça de teatro está sujeita ao cronotopo específico que é a divisão em cenas e a elipse dos momentos não representados. Além disso, como lembra Vigotski, complicações temporais, entrelaçamentos fazem com que nada ocorra de acordo com o "programa prescrito". Esse tempo da suspensão é ampliado pelo fato de as personagens falarem uma língua estrangeira, aqui a do jogo precioso.

A tensão aqui ocorre portanto entre a história, a maneira como ela é tratada e as personagens. Acrescente-se a isso a "corporeidade mental" de vários atores que interpretaram esse papel.

Isso posto, os três capítulos finais de Vigotski sobre a psicologia da arte enquanto tal apresentam problemas. Vigotski parte de considerações de "psicologia geral" sobre a sensação, a emoção e a imaginação que não podem apreender bem a especificidade da ação em nós de tal ou tal obra. Por outro lado, Vigotski pensa que a gravidade da emoção é a sua relação com a energia e se questiona sobre a relação entre a violência do dispêndio e, por outro lado, a economia do dispêndio que a obra de arte proporcionaria. Pareceme que este é um esforço inútil (relacionado com a problemática dos teóricos da época citados por Vigotski). É necessário buscar explicar o que é relativamente claro e culturalmente condicionado: a variedade de modos de repercussão da obra de arte em nós através do desconhecido de uma energética. Melhor, parece-me, partir da diversidade de obras e seus modos de recepção. Nem que fosse da diferença entre a obra como choque instantâneo e a obra concreta na qual se entra pouco a pouco. Mas também da diferença entre o primeiro choque da leitura do primeiro romance e a leitura culta de alguém que "sabe muito". Ou da diferença entre as formas que podemos perceber como próximas a nós e aquelas que nos impressionam pela sua distância.

E, de fato, muito do que busca Vigotski está na cultura, no modo como a arte muda nossas relações com nossos próprios sentimentos. Vigotski cita Freud: quando vejo um perigo, tenho medo e fujo, o útil é a fuga; quando estou em um espetáculo, eu não fujo, mas o útil é a nova disposição psíquica na qual o espetáculo me coloca. Para caracterizar a repercussão em mim, não é a força da emoção que conta, mas a sua especificidade. Eu diria que sua capacidade é não de reforçar nossas inclinações, mas nossas capacidades de nos "alterizar". A arte muda a semiologia da tristeza (não se trata de seu devir "social" como tal), através do ritmo da obra. O ritmo seria então paradoxalmente, por um lado, o primeiro modo de pensar, de socializar, de tornar comum o interno. Encontraríamos Marr e a teoria da música como primeira linguagem ou, simplesmente, a experiência banal da troca corporal da mãe (ou daquele ou daquela que acalanta) e da criança. Mas, na verdade, a obra de arte nos faz entrar, ao contrário (como na novela de Búnin ou na variação de estilos em Hamlet), em movimentos rítmicos que não estão inscritos na corporeidade primeira.

É o que Vigotski especifica quando diz que a catarse aristotélica é provavelmente devido ao fato de que o sentido formal, seja o sentido global realizado pelo espaço de suspensão (do espetáculo ou da leitura solitária), seja o sentido específico realizado pela forma discursiva, entra em conflito com o sentido realizado pela materialidade do que é representado. Voltando a Shakespeare, Vigotski cita a crítica que Tolstói faz a Shakespeare: "as personagens de Shakespeare fazem e dizem constantemente coisas que não só não são suas, mas também não têm nenhuma utilidade". Vigotski observa sem dificuldade que é justamente assim que a peça pode agir enquanto peça. E que não há economia de sentimentos em um sentido neurológico, mas no sentido de a tristeza representada não ser mais a tristeza real. Vemos como essa teoria da diferença dos modos de ser da obra de arte se opõe a uma pesquisa "psicológica" demais do que poderia ser a "identificação" do herói. Ressalto, de passagem, que essa noção parece colocar muitos problemas.

- Em primeiro lugar, o da modalidade: sabemos de que modo existe "relação" entre aquele que percebe o herói e o próprio herói? Podem-se partilhar seus valores, sua maneira de ver, sua imagem, querer ser como ele. Mas não é a mesma coisa.

- Ademais, não seria melhor dizer que há igualmente participação intensa nos outros como outros: as crianças, se somos adultos, os estrangeiros, a mulher para o homem...

O caminho indicado por Vigotski nos leva mais a pensar sobre a significação do espaço de suspensão, que é o espaço "estético", como modificando justamente nossa relação cotidiana com a alteridade dos outros e, assim, de nós mesmos. Através de toda obra,

François | Trad. Cunha | Dialogismo das "vozes" e heterogeneidadeconstitutiva do sentido. o "literário"... 
estamos em outro mundo, do ponto de vista do espaço, do recorte do tempo, da forma como são dados os heróis que transcendem a oposição real-irreal, verossímil-inverossímil, como revela o universal cultural dos demônios, das fadas, das bruxas, dos vários tipos de super-homens ou a comunicação imediata que parecem ter as crianças com uma sociedade heterogênea de gigantes, lobos ou raposas que falam. Seria, provavelmente, necessário generalizar ainda e dizer que nossa percepção do presente, do "real" é completamente imbuída de imaginário, quer se trate de vestígios de vida passada, quer de nossos imaginários sociais ou individuais, o que constitui "pacotes sentido" - ou, se quiserem, "complexos" - , como conjuntos de sentidos-força difíceis ou impossíveis de resolver por meio de elementos. Especialmente porque eles não nos são dados como representações, mas como formas de perceber, esquemas de ação ou de repercussão em nós. O que Vigotski resume assim, citando com aprovação Molojavi S., “[...] o pensamento, como a imagem, é um condensado de atitudes da consciência em relação a um fenômeno" (VIGOTSKI, 2005, p. 358).

Podemos, então, voltar ao início do livro e à relação com a psicanálise. É verdade que não sabemos como age a arte. Nesse sentido, é "inconsciente". Mas não é necessariamente o inconsciente freudiano, que propõe um princípio de prazer-descarga muito amplo. Perde-se então a forma mesma da literatura, da obra. Assim Vigotski considera que a única análise precisa de Freud é a do chiste, porque leva em conta o contraste entre o sentido esperado, o sentido produzido e a forma que permite o duplo sentido. (Da mesma forma, em lugar de querer reduzir o sonho ao papel de "guardião do sono", poderíamos nos interessar pelo prazer próprio de sua forma, pelo papel fundamental da sedução positiva do sonho como "imagem-enigma". O sonho seria uma espécie de oposto do chiste: a irrupção do enigma, e não do outro sentido).

A última dificuldade do texto da Vigotski vem provavelmente do seu aspecto inacabado e do fato de que não é óbvio que se pode encontrar a mesma relação "estética" nos vários tipos de textos de que ele nos fala, muito menos em outros. Caso contrário, efetivamente vamos sempre encontrar "espaço de suspensão" e sentido específico realizado pelo estilo.

\section{VOLOCHINOV, BAKHTIN, VIGOTSKI}

A partir daqui, podemos voltar para o que é diverso e o que é comum nesses autores. Em primeiro lugar, trata-se de "materialismo"? Obviamente, esse não é o problema de Bakhtin. Essa é uma questão central para Volochinov, como será para Politzer.

Será que sou "traidor" por não me interessar muito por esse problema? Há uma polissemia evidente em "materialismo". Mas, sobretudo, o principal problema vem da dominação do capitalismo em nossa sociedade, e não de uma escolha teórica entre materialismo e espiritualismo. A partir disso, quando Politzer procura fazer uma psicologia do drama humano ou quando Volochinov faz a teoria da ideologia do cotidiano, da ideologia misturada com a experiência não linguageira, integrada ao movimento corporal em oposição a uma teoria das características linguageiras da linguagem interior, suas análises me parecem concretas, independentemente de referência teórica ao "materialismo". Da mesma forma, é "concreto" o esclarecimento que Volochinov traz sobre a contradição entre a língua materna e a língua estrangeira ou aquela entre minha fala e a forma como o outro me retorna: "você disse". Quem de nós não está cheio de "prévia convicção" de que sua fala é transparente?

Não vou voltar aqui à contribuição de Bakhtin sobre a centralidade do "dialogismo", já apresentada acima. Bakhtin (contra o imaginário de Volochinov da sociedade onde todas as contradições desaparecem) se interessa pelo aspecto permanente dos conflitos. Assim, nos seus Apontamentos, "[...] só um polifonista como Dostoiévski foi capaz de sondar na luta entre opiniões e ideologias (de várias épocas) o diálogo inacabado em torno das últimas questões (no grande tempo). Outros se ocuparam de questões solucionáveis no âmbito de uma época" (BAKHTIN, 2003, p. 388).

Finalmente, parece-me que há uma clara relação entre Bakhtin e Vigotski em sua caracterização da forma estética, como proporcionando um diálogo que a vida cotidiana ou a obra medíocre não propiciam.

Seria uma banalidade dizer que, desses três autores, apenas Vigotski se interessou pela criança (apesar da citação que apresentamos de Bakhtin). Não obstante uma análise da linguagem e da cultura, que considera apenas as relações entre adultos, pode perder a estranheza do ser humano, na medida em que é na criança que primeiro se manifesta a contradição entre o mundo vivido e o mundo 
dito (pelos adultos). Mas não poderíamos dizer que essa distância permanente é precisamente a da "ideologia do cotidiano" e de seus componentes heterogêneos? Acrescente-se que mais talvez do que os outros autores, Vigotski soube enfatizar a impossibilidade de separar pensamento e sentimento, na unidade do "modo de repercussão" em cada um de nós.

O que não exclui as tensões nas relações instáveis entre as esferas do conhecimento, do imaginário, da presença do outro, da estética, da moral, que nenhum metadiscurso coloca definitivamente no lugar: podemos dizer que o objetivo da humanidade seria transformar todo o não-verbal em verbal. "Dialogismo" remete ao fato de que um texto, apesar de sua finitude, nos leva a pensar em outra coisa que não teríamos pensado sozinhos, diferentemente da "intenção do autor" e o que ele diz no sentido estrito. Isso faz com que o modo de repercutir dos textos permaneça em aberto.

\section{CONCLUSÃO: UMA TENTATIVA DE REFLEXÃO SOBRE AS FUNÇÕES DA “TEORIA", O "DIALOGISMO” E A PEDAGOGIA}

Podemos primeiro observar um horizonte de problemas não esclarecidos. A diversidade de vozes nos textos foi mais analisada que a diversidade de nossos modos de percebê-las, mais do que, de modo geral, as formas, os modos pelos quais os "outros" estão presentes em nós, algumas vezes, obviamente, como lembranças explícitas. O mais das vezes, sem dúvida, se presentificam como esquemas, como modos de ser, como lacunas. Da mesma forma que não temos uma teoria clara das diferentes formas de pensamento. Por exemplo, podemos provavelmente falar de um pensamento com predominância do verbal, com predominância de imagens ou com predominância de esquemas práticos. Sabemos o quanto essa predominância não é exclusiva, mas é acompanhada de um pano de fundo de atitudes, de movimentos (o que faz com que, por exemplo, a "linguagem interior" nunca seja constituída apenas de palavras)? Provavelmente, não.

\section{a) Teoria?}

Mas primeiramente sabemos o que pode ou deve ser a "teoria"? Uma tradição filosófica antiga (mas que tem ramificações na vida diária, quando se supõe que uma definição deve dar a "essência" do objeto que ela define) triunfa em Hegel, em cuja Estética presume-se que se diz a verdade sobre a arte, a filosofia do direito, a verdade da lei, etc., embora haja também a ideia de que a teoria só pode ser desenvolvida uma vez quando a história aconteceu. Entretanto, Freud, por exemplo, quis definir a "natureza" do sonho, Marx, a da luta de classes. E essa ideia "essencialista" permanece, embora se reconheça que há também o "know how" irredutível à teoria: a mão do artesão ou a cozinheira da equipe, que, sozinha, pode conseguir que as crianças psicóticas falem..., ou a incapacidade do pintor, músico ou escritor de dizer "de onde vem a inspiração", "como eles fazem". Assim também se pode continuar a falar de "inteligência", de "inconsciente" ou de "diálogo", mesmo reconhecendo que as condições para aplicação desses objetos teóricos são indefinidamente múltiplas e variadas.

Parece-me que uma reflexão sobre o "dialogismo" também deve levar à ideia de fuga do sentido, de impossibilidade de não acrescentar determinações e mudar pontos de vista. Por um lado, não existe um "ponto de vista de Sirius". Por outro, não éo discurso mais geral que é necessariamente o mais "verdadeiro. E há muitos exemplos do ridículo (e/ou da violência) daqueles que argumentam que eles são os "verdadeiros defensores da razão". Há, de um lado, conhecimentos transmitidos; de outro, o conjunto daquilo com que nos deparamos, do que não sabemos como pensar.

Há aqui um "dialogismo" que se transforma em babelismo, sem acordo sobre o que constitui um problema digno de ser pensado, nem um ponto de partida razoável, sem que saibamos bem qual é a relação entre a teoria e a prática, especialmente quando se trata de "comunicar". Assim, com referência à pedagogia, podemos duvidar que seja necessário partir de uma "boa definição" da narrativa para "avaliar", em seguida, as narrativas de crianças.

Sobretudo porque não há, de um lado, especialistas do conceito e, de outro, espíritos voltados para o concreto. Basta voltar à história da filosofia para constatar que não há "teoria pura". Há textos em que a função de elaboração e discussão de conceitos é dominante. Isso não os impede de apresentar hipóteses ou relatar exemplos. E também apelar para noções não elaboradas e para a tradição

François trad. Cunha | Dialogismo das "vozes" e heterogeneidade constitutiva do sentido. o "literário". 
inscrita na língua. Em suma, não há dúvida de que não existe nenhuma "teoria” pura. Poderíamos propor, ao contrário, que a "filosofia" é uma subespécie do gênero "literatura" e, nesse sentido, desfigura-se tanto a filosofia, resumindo-a, quanto um romance ou um poema. Há, é claro, “diálogo” nos filósofos, ideias feitas, irrupções, especialmente uma cadência, um ritmo.

Da mesma forma, a ligação entre discurso teórico e mito continua presente, sem falar de Platão, por exemplo, em Freud: a horda primitiva, o assassinato do pai, a refeição totêmica? A forma narrativa não é o outro do "puro" teórico. Ou ainda, qualquer que seja o status da psicanálise, ela é melhor apresentada com a exposição de uma imagem do aparelho psíquico ou contando uma análise? (Do ponto de vista de quem é uma outra questão). É necessário fazer uma teoria do diálogo pedagógico ou mostrar exemplos de alternância dos momentos pacificados, dos conflitos produtivos ou não (com a questão complicada dos momentos produtivos ocultos)?

Acrescente-se que, provavelmente, podemos considerar toda teoria monológica como um diálogo eliminado, a teoria não se baseando apenas no contato direto com os fatos, mas polemizando contra os enunciados do outro. Ou melhor, poder-se-ia opor falsos diálogos que têm apenas a forma de diálogo: o Mênon, os diálogos socráticos, as listas de opiniões relatadas por Aristóteles ou as "revisões da literatura" no início das teses seriam exemplos. Mas o Banquete seria mais um diálogo, qualquer que seja a exotopia do autor, porque não há nenhuma “teoria verdadeira” e os vários discursos não se respondem diretamente.

Em todo caso, não se pode isolar um conceito simples que oporia de uma vez por todas o geral e o particular, que nos diria: "a sociedade é ..." ou “o sentido é ...". Assim, não existe algo unívoco que seria a "coação social" ou a "classe social". Em algum momento, poderá ser a família que representa ao mesmo tempo a necessidade dos outros e seu aspecto coercivo, como a "classe social" pode, de acordo com o momento, ser vivida por intermédio do bairro onde se mora, as limitações que os pais impõem, a riqueza dos outros, a ausência de futuro... Um pouco como no caso dos “irmãos" mencionados por Vigotski, a "boa definição abstrata” não anula as determinações concretas. Assim, não se deve definir um grupo, uma classe social ou uma classe de escola, seja do exterior pelas coerções agindo sobre ela, seja do interior por uma consciência de pertencer a um mesmo grupo, mas, para o que nos interessa aqui, pelo conjunto de convergências e divergências em relação ao fácil ou ao difícil de significar.

A narrativa e particularmente a do romance é o lugar onde se manifesta a heterogeneidade de pontos de vista (embora essa heterogeneidade também possa ocorrer na confissão ou no autoquestionamento). De qualquer forma, o romance mostra o entrelaçamento do particular e do geral, o que é apreendido do interior e visto do exterior: uma angústia pode ser descrita como sentimento ou como descrição do lugar em que ela ocorre. Um romance também pode, sem dúvida melhor do que a maioria de nossas vidas, colocar em relação o cotidiano e as "experiências-limite". Acima de tudo, em vez de opor "realidade" e "ficção", o romance introduz uma continuidade entre o realmente experimentado e a experiência indireta vicária. Mais do que a teoria, ele nos mostra o entrelaçamento de diferentes momentos da vida, de suas sociabilidades diversas, solidões e de seus entornos; ou ainda, $o$ elo entre o "representado como presente" e os diferentes "mundos ausentes" de cada um de nós.

O objetivo não é determinar essências, em oposição às aparências, o profundo contra o superficial. Mas nos orientar a partir de nossas dificuldades, do pensamento dos outros, bem como de fatos gerais irredutíveis: assim a diferença de gerações torna necessário um diálogo sempre arriscado. E este diálogo não se reduz ao embate de palavras, mas ao dito e ao não dito, ao tematizado e ao pano de fundo, ao fácil de dizer e ao difícil de dizer, todos esses aspectos não sendo obviamente partilhados por nós da mesma maneira.

\section{b) Dialogismo e heterogeneidade}

Pode-se perguntar se pode haver uma "verdadeira teoria" do dialogismo. Um pouco como se pode perguntar se o romance de Dostoiévski seria, pelo seu dialogismo, uma forma de "romance por excelência".

Como vimos, a heterogeneidade das "vozes" não se opõe à "exotopia” do autor, ao seu potencial de metteur en scène ${ }^{18}$. Um parêntese: há, certamente, nos últimos escritos de Tolstói uma forma monológica de pregação. Mas, se compararmos Anna Karenina a

${ }^{18}$ N.T.: Expressão francesa, mas dicionarizada por Houaiss, usada para se referir a diretor de cinema ou de teatro. 
romances de Dostoiévski, parece-me que a diferença desaparece, pois aqui encontramos os termos do problema colocados por Vigotski: o enredo e sua temporalidade própria e o desenvolvimento efetivo do romance não coincidem, como mostra o movimento do romance de Búnin. Falar de "estética” remete ao que se revela pelo estilo do texto em contraste com as significações que podem ser resumidas. Assim como não se trata realmente de diferentes “vozes”, mas de gêneros, lugares que adota sucessivamente Hamlet, enquanto a vida cotidiana impõe a uniformidade da aparência. Nesse sentido, a obra de arte é similar ao pano de fundo próprio de cada um de nós, com seu horizonte de recepção, estável por um lado, dependente da pluralidade cultural, por outro, que não podemos tematizar sem desfigurar. Sabemos o que há de falso em todos os discursos respondendo a perguntas como: "Qual é o seu temperamento? Sua forma de ver?...”. Poder-se-ia encontrar aqui as perguntas que foram feitas sobre a separação absoluta feita por Bakhtin entre o que faz parte da ética como dominada pelo futuro e o que faz parte do ritmo.

O diálogo é cheio de "forças silenciosas". Em primeiro lugar, a força das presenças corporais. Em seguida, o papel da presença do ausente, por exemplo, como o sentimento de ameaça ou de lacuna impede de identificar diálogo e troca de palavras.

- Se colocarmos o problema em termos de recepção e compreensão, poderíamos perguntar sobre a abertura proporcionada pelos não-ditos subjacentes, quer se trate de conhecimentos, quer se trate de significações vividas, como é o horizonte de toda percepção, ou das que tomam a forma de pensamento associativo. Tudo isso comporta algo de anônimo-genérico ou de mais específico de um "nós” ou de um "eu”, através das significações mais ou menos móveis e dizíveis.

O exemplo mesmo de Vigotski nos mostra que é bem melhor partir das obras para chegar aos panos de fundo do que fazer teorias "introspectivas" ou "objetivas" do aparelho psíquico. É na relação com "terceiros”, que são as obras, que se manifesta de modo claro a nossa relação de semelhança-diferença e a evidência segundo a qual tudo "isso" pressupõe um pano de fundo. Note-se que nessa colocação de um pano de fundo não há diferença entre "explicar" e "compreender", uma vez que "explicar" aqui não significa "dar conta causalmente", mas esclarecer o caráter implícito do nosso mundo ou do mundo dos outros. Não se dá conta de uma decisão política por meio de movimentos de elétrons. Mas isso não significa que sabemos a priori o que vai entrar em uma "boa descrição" de tal decisão.

- O dialogismo-heterogeneidade provém em primeiro lugar do fato de que nenhum objeto tem uma única faceta. E não se pode esquecer a alternância dos nossos ritmos, o que faz com que uma teoria dos "afetos" simples não dê conta do movimento da criança ao mesmo tempo tentada pelo novo e hesitante em face do que assusta. Assim, um modelo como aquele que opõe pulsões e interditos isola um traço particular da ambivalência consubstancial do sujeito tal como se encontra também nos desejos alternados de calma e de risco, de solidão e de comunidade.

Podemos supor aqui apenas que a relação de si a si provém exclusivamente da relação externa dos outros a nós. Como não são os outros que levam a criança a esse espanto que Wallon, após Baldwin, chamou de "reação circular", a da criança que se dá a perceber levando uma parte do seu corpo (o pé, por exemplo) para o seu campo de visão. Mas isso é apenas um exemplo. Há uma pluralidade, uma defasagem de nós para nós mesmos que não pode ser reduzida à diferença da palavra do outro em nós, como se pode pensar que uma grande parte da "doença mental" se deve à falta ou ao excesso de diferenciação de si para si.

— Toda uma tradição teórica considerou antes de tudo a emoção como evento, irrupção: parece que tanto o súbito quanto o durável caracterizam os modos de repercussão em cada um de nós. Vigotski nos lembrou que a primeira emoção, segundo Descartes, é a admiração. Mas também fazem parte do clima sentido a permanência do habitual, o que é vivido como evidente, podendo ser o que é reconfortante e/ou irritante, com todas as ambivalências da nossa relação com a esperança e o temor do surgimento do novo, ou até o horrível. O que vai se complicar com outros níveis de modalização: "Eu estou bem, mas é horrível" ou "Eu deveria estar feliz, mas eu não sinto nada" ou "Sinto algo, mas não sei o que..." O que se nomeia "subjetividade" é constituído de modalidades de sintonia-distonia, modalidades variáveis em si mesmas e no modo como elas são pensadas.

Mas, de um modo geral, não se pode constituir uma lista a priori de sentimentos, nem pensá-los claramente na sua articulação corporal-social. Cada época tem levado a novas organizações dos modos de sentir a relação com o mundo, com os outros (alguns outros) e consigo mesmo. Pode-se evocar o Spleen de Baudelaire, mas igualmente o sentimento de honra ou as variações dos limites

François trad. Cunha | Dialogismo das "vozes" e heterogeneidade constitutiva do sentido. o "literário". 
do "amor ao próximo", com o problema das palavras transversais - raiva, depressão ou melancolia - que atravessam o tempo, não necessariamente com as mesmas modalidades de sentidos. Da mesma forma que variam os modos específicos de sentir tal personagem ou tal evento, sua aura, tanto no modo como "nossos mortos" são esquecidos ou se tornam na nossa lembrança um centro de referência, quanto na figura do Cristo evocado por Dostoiévski. Note-se que o que faz a cultura é, por exemplo, que essa figura de Cristo pode agir em nós, sejamos cristãos ou não, como Hamlet nos emociona em nosso "espaço de suspensão".

Então, podemos dizer que mais do que o discurso da ciência, da filosofia, da psicanálise, o discurso "literário" nos dá uma dimensão fundamental de nossas vidas? Bem como a relação ao que não ousamos dizer ou a presença em nós, não teórica de nossos "outros", seja a alteridade próxima das crianças para os adultos, das mulheres para os homens ou vice-versa, seja a alteridade mais longínqua do estrangeiro ou do distante no tempo? Nesse sentido, o "literário" seria uma mediação necessária entre nós e os outros, especialmente adultos e crianças e/ou nós e nós mesmos. O que poderia ser uma explicação para o uso quase universal da narrativa como um meio entre as gerações, embora as crianças não possam compreender as "histórias" dos pais e dos professores como lhes são contadas, nem se saiba nunca o que vai ocorrer nessa passagem. As crianças estão sujeitas aos ideais (eventualmente contraditórios) dos pais, depois dos adultos em geral, à impossibilidade de estar de acordo com os seus desejos (eventualmente contraditórios) ou à falta de imagens do que elas podem ou devem ser. Ao mesmo tempo, as crianças pensam conforme seus próprios desejos. O que se revela em seus textos simultaneamente forçados a ser conforme a norma adulta e de forma que não poderíamos produzir nós mesmos.

Mas voltar ao espaço da cultura é voltar para a natureza obscura da relação entre linguagem e pensamento. Vamos nos limitar aqui a alguns pontos.

a) Como Vigotski insistiu e, apesar de muitos esquecerem, o pensamento como forma de organizar um heterogêneo em função de um ausente pode se fazer sem a linguagem, em qualquer atividade motora, por exemplo.

b) Não há pensamento sem afeto, sem atmosfera sentida, a qual nos dá particularmente o difícil de dizer do mundo do ser, de nosso lugar em relação ao mundo, ao que falamos, aos outros, a nós mesmos. Naturalmente esses modos de repercussão comportam talvez constâncias, certamente variações, mas é disso que partimos e é isso que o diálogo, para o bem ou para o mal, permite sempre modificar.

c) Há uma massa de pensamentos que não pode ser feita sem linguagem. Mas isso não exclui o pano de fundo de não-dito e tudo a que um texto pode dar origem (compreensão responsiva).

d) Nós não lidamos com a língua, mas com as línguas (dos outros, de si, materna e estrangeira...) e com os gêneros, sem que se possa, portanto, falar das relações do "pensamento" e da "linguagem". Háo pensamento definidor, o pensamento narrativo, o pensamento associativo, o pensamento sonhador e todos esses pensamentos de maneiras diferentes remetem uns aos outros.

e) E também, todo pensamento é movimento, que pode sempre se fixar em fórmula, o que, em particular, ameaça aquele que algum palco físico ou moral autoriza a "falar do alto".

f) Enfatizamos a noção de "espaço de suspensão", na cerimônia, na solidão ou na lembrança.

g) Da mesma forma que podemos voltar ao modo como as significações desenhadas pelos próprios movimentos do texto não são resumíveis.

Para finalizar essa conclusão, poderíamos voltar para a divisão feita por Bakhtin, já mencionada, entre o domínio da ética, o domínio da estética, o domínio do conhecimento e o domínio da fé. Não vamos falar do último. Mas cada um desses domínios, por sua vez, subdivide-se: a moral dos interditos não é a mesma coisa que a moral das orientações individuais, a moral do cotidiano não é a das situações extremas. Assim como a multiplicidade dos tipos de objetos e das relações estéticas nos proíbe uma definição unívoca do "belo", e saberes cotidianos, habilidades, saber histórico, saberes estabilizados e hipóteses não são "saberes" da mesma maneira. Entre 
os modelos físicos e o conhecimento da história das civilizações, não há medida comum. Não há, de um lado, a ciência, de outro, a opinião ou a ideologia: há sobretudo diferentes formas de consciência, necessariamente mais ou menos inadequadas. Cada indivíduo, além disso, situa-se de forma diferente nessas diversas dimensões (por exemplo, em função de sua capacidade de suportar a insegurança, ou até do prazer que sente em se movimentar nessas dimensões). Do mesmo modo, se o pensamento de Bakhtin está no centro de uma reflexão sobre a diversidade de gêneros substituindo a infeliz dicotomia língua-fala individual, resta-nos pensar sobre o que pode ser o modo de repercussão das diferentes obras em nós.

Voltemos a dois exemplos de Dostoiévski: o herói de Memórias do subsolo pode sempre ser visto como uma caricatura do movimento do pensamento, ou então vamos nos divertir com algumas hesitações ou com o modo como seus devaneios são sempre contraditos pelo seu comportamento efetivo. Ou então, vamos nos perguntar se não há algo de nós nele.

Aqui eu me aproximo da conclusão que dá Todorov na edição que consultei das Memórias do subsolo. O modo como a jovem prostituta que vem à casa dele abraça-o lembra em seu silêncio o beijo do Cristo no Grande Inquisidor. Podemos ser ou não crentes ou, se somos crentes, podemos perceber de muitas maneiras a relação do Cristo com a prática institucional das igrejas que o seguem.

Contudo a mise en scène ${ }^{19}$ de Dostoiévski nos torna sensíveis a um modo de ser, a uma figura de sentido em que as oposições entre afetivo e intelectual ou estético, religioso e ético já não têm muito sentido. Em outras palavras, nosso foro interior é tecido de imaginários, que são condição do sentido de nossa "relação com o real", para além das palavras monológicas solenes. O espaço de suspensão que é a peça de teatro, o filme ou o romance são os lugares onde a generalidade e a particularidade, a ordem do mundo e os eventos, as diferenças inevitáveis entre o dito e o que é sentido se evidenciam. E essa diversidade cultural nos impede de pretender dizer aos outros como o mundo deve repercutir neles. Para voltar à questão do "cotidiano e do literário", em um primeiro momento, a obra literária está no plano da suspensão da "ficção" do irreal. A questão que se coloca, eu penso como os três autores, é a do modo como nossa relação ao "real" é modificada por essa ficção, especialmente pela forma como a ficção ilustra a diversidade de perspectivas, o entrelaçamento indissolúvel do que é comum com a diversidade de perspectivas, de resistência das coisas ao irrealreal do passado, do futuro, do "como se", do virtual. É essa mistura que é constitutiva do que chamamos de "sentido". Há seguramente um "princípio de realidade" que resiste, por exemplo, na irreversibilidade do tempo, na forma concreta de não ser capaz de remover o erro realizado nem impedir o percurso para a morte. Mas é o romance (e não a "ciência") que nos apresenta a realidade múltipla dos projetos, das imagens, das teorias, das lembranças que fazem nosso real-irreal. É o que se apresenta sob a forma de "ideologia do cotidiano", na mistura em nós de nossas significações corporais, do que recebemos das ideologias públicas e do modo como nós as digerimos, narramos a nós mesmos ou as vivemos sem dizê-las.

Não estamos confrontados tanto a uma gigantomaquia dos materialistas contra espiritualistas quanto ao nosso lugar em um complexo técnico-capitalista de fabricação de indivíduos produtores-consumidores. Daí a nossa dificuldade de pensar e de ter nossos "modos de repercussão", mais ainda de ajudar nossos sucessores a pensar e a reagir por eles mesmos, em um mundo em que as tradições de transmissão cultural praticamente desapareceram. Desse ponto de vista, poderíamos opor duas "funções da escola": a escola como elaboração de modos diversos de estar juntos, a escola como lugar do lento aprendizado de saber "pensar só".

Eu gostaria de terminar com uma longa citação de Bakhtin (1971, p.378-379:

Para cada indivíduo, todas as palavras se dividem nas suas próprias palavras e nas do outro, mas as fronteiras entre elas podem confundir-se, e nessas fronteiras desenvolve-se uma tensa luta dialógica. Entretanto, nós afastamos, abstraímos, essa questão quando estudamos uma língua e os diversos campos de criação ideológica, pois existe a posição abstrata do terceiro que se identifica com a "posição objetiva" como tal, com a posição de qualquer "conhecimento científico". A posição do terceiro é plenamente justificada onde um indivíduo pode colocar-se no lugar do outro, onde o homem é perfeitamente substituível e justificável em situações e na solução de questões em que não se faz necessária a personalidade integral e ímpar do homem, isto é, onde o homem, por assim dizer, se especializa, exprimindo apenas uma parte da sua personalidade separada do todo, onde ele não

${ }^{19}$ N. T.: Palavra francesa também dicionarizada que remete à arte da encenação teatral ou cinematográfica. 
atua como eu mesmo, mas "como engenheiro", como físico", etc. [...] As ciências do espírito; seu objeto não é um, mas dois "espíritos" (o que é estudado e o que estuda, que não devem fundir-se em um só espírito).

Isso vale igualmente quando se trata de uma obra, e não de um espírito. Por exemplo, entre a percepção ingênua e a percepção culta, não há escolha e cada um dos dois pode nos modificar. Por exemplo, na situação de alguém que não "compreende", isto é, que não está na posição do terceiro, daquele que pode parafrasear.

Podemos dizer com Bakhtin que há momentos em que o monologismo apaga a pluralidade de vozes conflitantes. Outros em que as diferenças se impõem, com a particularidade de que não sabemos onde estamos. Podemos acrescentar essas palavras um pouco elípticas do texto final de Bakhtin, Metodologia das ciências humanas: "o 'inefável' como limite flutuante, como ideia reguladora' (no sentido kantiano) da consciência criadora" (BAKHTIN, 2003, p. 386).

É (relativamente) fácil ter consciência do que foi mal dito ou dito a mais. É mais difícil ter uma "boa relação" com o que não está dito, com o que sentimos como difícil de dizer ou ainda com o que não conseguimos ser sensível.

\section{REFERÊNCIAS}

BAKHTINE, Mikhail. Problèmes de la poétique de Dostoïevski. Paris: L'âge d'homme, 1970.

BAKHTINE, Mikhail. L'euvre de François Rabelais et la culture populaire au moyen âge et sous la renaissance. Paris : Gallimard, 1970.

BAKHTINE, Mikhail. Esthétique et théorie du roman. Paris : Gallimard, 1978.

BAKHTINE, Mikhail. Esthétique de la création verbale. Paris: Gallimard, 1984.

BAKHTINE, Mikhail. Pour une philosophie de l'acte. Paris: L'âge d'homme, 2003.

BALL ARNETHA, F.; WARSHAUER. Freedman Sarah (Ed.). Bakhtinian perpsectives on language, literacy and learning. Cambridge University Press, 2004.

BAZERMAN, Charles. Intertextualities: Volosinov, Bakhtin, literary theory and literacy studies. In: BALL, Arnetha F.; WARSHAUER, Freedman Sarah (Ed.). Bakhtinian perpsectives on language, literacy and learning. Cambridge University Press, 2004. p. 53-65.

BAZERMAN, Charles. Shaping written knowledge, the genre and activity of the experimental article in science. Wisconsin: The University of Wisconsin Press, 1988.

BAZERMAN Charles, Constructing experience, Southern Illinois University Press, 1994.

BERNARD, Gardin. Volochinov ou Bakhtine ? La Pensée, n. 197, 1978. [reedição - Langage et luttes sociales. Limoges: Editions Lambert-Lucas, 2005. 69-86.

BERNIE Jean-Paul, Apprentissage, développement et significations. Bordeaux, Presses Universitaires de Bordeaux, 2001.

BERNIE Jan-Paul. Genres discursifs scolaires, genres de l'activité et conceptualisation. In: Apprentissage, développement et significations. Bordeaux : Presses Universitaires de Bordeaux, 2001. p. 155-172.

BROSSARD, Michel; FIJALKOW, Jacques, Apprendre à l'école, perspectives piagetiennes et Vigotskiennes. Bordeaux, Presses Universitaires de Bordeaux, 1998.

BROSSARD, Michel. Vigotski, Lectures et perspectives de recherche en éducation. Lille, Presses Universitaires du Septentrion, 2004.

BRUNER, Jerôme, ...car la culture donne forme à l'esprit, de la révolution cognitive à la psychologie culturelle. Paris : Eshel, 1991

Fórum linguistic., Florianópolis, v.13,n.2, p.1260-1294, abr./jun.2016. 
CASTEL, Robert; HAROCHE, Claudine. Propriété privée, propriété sociale, propriété de soi, Entretiens sur la construction de l'individu moderne. Paris, Fayard, 2001.

CLOT, Yves (Ed.). Avec Vigotski. 2. ed. Paris: La Dispute, 2002.

ELTCHANINOFF, Michel. Dostol̈evski, Roman et philosophie. Paris: P.U.F., 1998.

FONTANE, Theodor. Mes années d'enfance, Roman autobiographique. Local : Chambon poche, 1996.

FRIEDRICH, Janette. Les traces de Marr dans le livre de K. Megrelidze Osnovnye problemy sociologii my`slenynija. Cahiers de l'ILSL, Université de Lausanne, n.20, p. 109-125, 2005.

GARDIN, Bernard. Langage et luttes sociales. Limoges : Lambert-Lucas, 2005.

HUMBOLDT Wilhelm von, De l'esprit de l'humanité et autres essais sur le déploiement de soi. Local: Premières pierres, 2004.

JANETTE, Friedrich. Les traces de Marr dans le livre de K. Megrelidze Osnovnye problemy sociologii my ``lenynija, p. 109-125, 1937.

MEYERSON, Ignace. Les fonctions psychologiques et les œuvres. Paris : J. Vrin, 1948.

MIKA, Lähteenmäki. Sur l'idée du caractère de classe de la langue : Marr et Volochinov, Cahiers de L'Ilsl, n. 20, p. 161-175, 2005.

MORSON, Gary Saul. The process of ideological becoming, In: BALL, Arnetha F.; WARSHAUER, Freedman Sarah (Ed.). Bakhtinian perpsectives on language, literacy and learning. Cambridge University Press, 2004. p. 317-332.

POLITZER, Georges, Ecrits 2, Les fondements de la psychologie, Paris, Editions sociales, 1969.

ROCHEX, Yves. Vigotski et Wallon: pour une pensée dialectique des rapports entre pensée et affect. In: CLOT., Yves. (Ed.). Avec Vygotski. Paris: La Dispute, 2002. p. 121-1 $1^{4}$.

SERIOT, Patrick (Ed.). Un paradigme perdu : la linguistique marriste, Cahiers de l'ILSL, Université de Lausanne, n.20, 2005.

SERIOT, Patrick. Si Vico avait lu Engels, il s’appellerait Nicolas Marr. Cahiers de l'ILSL, n.20, p. 227-254, 2005.

VIGOTSKI, Lev. Pensée et langage .3. ed. Paris : La Dispute, 1997.

VIGOTSKI, Lev, Théorie des émotions, Etude historico-psychologique. Paris: L’Harmattan, 1998.

VIGOTSKI, Lev. Conscience, inconscient, émotions. Paris : La Dispute, 2003.

VIGOTSKI, Lev. Psychologie de l'art. Paris : La Dispute, 2005.

VOLOCHINOV, V.N. [Traduction parue sous le nom de Mikhail Bakhtine] Le freudisme. Paris : L'âge d'homme, 1980.

VOLOCHINOV, V.N. [Traduction parue sous le nom de Mikhail Bakhtine, celui de Volochinov en sous-titre entre parenthèses]. Le marxisme et la philosophie du langage, essai d’application de la méthode sociologique en linguistique. Paris : Ed. de Minuit, 1977.

WALLON, Henri, L'évolution psychologique des enfants. Armand Colin, 1941.

WERTSCH, James. Vigotski and the social formation of mind. Cambridge: Harvard University Press, 1985.

WERTSCH, James (Ed.). Culture, communication and cognition. Cambridge University Press, 1985.

Referências bibliográficas das obras traduzidas em português utilizadas nas citações

BAKHTIN, Mikhail. Para uma filosofia do ato. São Carlos: Pedro e João Editores, 2010.

BAKHTIN, Mikhail. Ofreudismo: um esboço crítico. São Paulo: Perspectiva, 2007.

François | Trad. Cunha Dialogismo das "vozes" e heterogeneidade constitutiva do sentido. o "literário". 
BAKHTIN, Mikhail. Estética da criação verbal. 4. ed. São Paulo: Martins Fontes, 2003.

BAKHTIN, Mikhail. Problemas da poética de Dostö̈evski. 2.ed. Rio de Janeiro: Forense-Universitária, 1997.

BAKHTIN, Mikhail [Volochínov, Valentin. N.]. Marxismo e filosofia da linguagem. 7. ed. São Paulo: Hucitec, 1995.

DOSTOIÉVSKI, Fiódor, Memórias do subsolo. São Paulo: Editora 34, 2009.

Os irmãos Karamázov. São Paulo: Editora 34, 2008.

FRANÇOIS, Frédéric, Essais sur quelques figures d’orientation. Limoges, Lambert-Lucas, 2009.

VIGOTISKI, Lev S. Psicologia da arte. São Paulo: Martins Fontes, 1999. 